\title{
RELATIONSHIP BETWEEN SOIL OXIDIZABLE CARBON AND PHYSICAL, CHEMICAL AND MINERALOGICAL PROPERTIES OF UMBRIC FERRALSOLS ${ }^{(1)}$
}

\author{
Flávio Adriano Marques ${ }^{(2)}$, Márcia Regina Calegari ${ }^{(3)}$, Pablo Vidal- \\ Torrado $^{(4)} \&$ Peter Buurman ${ }^{(5)}$
}

\begin{abstract}
SUMMARY
The occurrence of Umbric Ferralsols with thick umbric epipedons $(\geq 100 \mathrm{~cm}$ thickness) in humid Tropical and Subtropical areas is a paradox since the processes of organic matter decomposition in these environments are very efficient. Nevertheless, this soil type has been reported in areas in the Southeast and South of Brazil, and at some places in the Northeast. Aspects of the genesis and paleoenvironmental significance of these Ferralsols still need a better understanding. The processes that made the umbric horizons so thick and dark and contributed to the preservation of organic carbon $(\mathrm{OC})$ at considerable depths in these soils are of special interest. In this study, eight Ferralsols with a thick umbric horizon (UF) under different vegetation types were sampled (tropical rain forest, tropical seasonal forest and savanna woodland) and their macromorphological, physical, chemical and mineralogical properties studied to detect soil characteristics that could explain the preservation of high carbon amounts at considerable depths. The studied UF are clayey to very clayey, strongly acidic, dystrophic, and Al-saturated and charcoal fragments are often scattered in the soil matrix. Kaolinites are the main clay minerals in the A and B horizons, followed by abundant gibbsite and hydroxyl-interlayered vermiculite. The latter was only found in UFs derived from basalt rock in the South of the country. Total carbon (TC) ranged from 5 to $101 \mathrm{~g} \mathrm{~kg}^{-1}$ in the umbric epipedon. Dichromateoxidizable organic carbon represented nearly $75 \%$ of TC in the thick A horizons, while non-oxidizable $\mathrm{C}$, which includes recalcitrant $\mathrm{C}$ (e.g., charcoal), contributed
\end{abstract}

(1) Part of the doctoral thesis of the first two authors. Project funded by FAPESP. Received for publication in November 2009 and approved in October 2010.

(2) Researcher, Embrapa Solos/UEP Nordeste Rua Antônio Falcão, 402 - Boa Viagem CEP 51020-240 Recife (PE). Email:flavioadrianomarques@yahoo.com.br

(3) Professor, Colegiado de Geografia, Universidade Estadual do Oeste do Paraná - UNIOESTE - MCR/PR. Rua Pernambuco, 1777- Centro - CP 91, CEP 85960-000, Marechal Cândido Rondon (PR). E-mail:marciareg_calegari@hotmail.com

(4) Full Professor, Departamento de Ciência do Solo, Escola Superior de Agricultura "Luiz de Queiroz" - ESALQ/USP. Av. Pádua Dias 11, CP 9, CEP 13418-900 Piracicaba (SP). E-mail:Pablo@esalq.usp.br

(5) Associate Professor, Earth System Science Group, Wageningen University. P.O. Box 476700 AA Wageningen (Netherlands). E-mail:peter.buurman@wur.nl 
to the remaining $25 \%$ of TC. Carbon contents were not related to most of the inorganic soil variables studied, except for oxalate-extractable Al, which individually explained $69 \%(\mathrm{P}<0.001)$ of the variability of $\mathrm{TC}$ in the umbric epipedon. Clay content was not suited as predictor of TC or of the other studied C forms. Bulk density, exchangeable $\mathrm{Al}^{3+}, \mathrm{Al}$ saturation, ECEC and other parameters obtained by selective extraction were not suitable as predictors of TC and other $\mathrm{C}$ forms. Interactions between organic matter and poorly crystalline minerals, as indicated by oxalate-extractable $\mathrm{Al}$, appear to be one of the possible organic matter protection mechanisms of these soils.

Index terms: Ferralsols, tropical soils, soil total carbon, soil organic carbon, pyrogenic carbon, soil charcoal, umbric epipedon

\title{
RESUMO: RELAÇÕES ENTRE O CARBONO OXIDÁVEL DO SOLO E ATRIBUTOS FÍSICOS, QUÍMICOS E MINERALÓGICOS DE LATOSSOLOS COM HORIZONTE A HÚMICO
}

\begin{abstract}
A ocorrência de Latossolos com horizonte A húmico hiperdesenvolvido ( $\geq 100 \mathrm{~cm}$ de espessura) nos trópicos e subtrópicos úmidos é um paradoxo, pois os processos de decomposição da matéria orgânica nesses ambientes são bastante eficientes. Apesar disso, esses solos têm sido documentados nas regiões Sudeste e Sul do Brasil, com algumas ocorrências na região Nordeste. Aspectos da gênese e do significado paleoambiental desses Latossolos aguardam por melhor entendimento. Os processos que levaram o horizonte A a ser tão espesso e escuro e contribuíram para preservação de C orgânico (CO) em profundidades consideráveis nesses pedons são de especial interesse. Neste trabalho, oito Latossolos com horizonte A húmico hiperdesenvolvido (Lh) sob diferentes fitofisionomias (Floresta Ombrófila, Floresta Estacional e Savana Arborizada) foram amostrados e os seus atributos macromorfológicos, físicos, químicos e mineralógicos estudados, com o objetivo de relacioná-los com a preservação de $C O$ em profundidade. Esses Lh são argilosos a muito argilosos, fortemente ácidos, distróficos, álicos e muitos possuem fragmentos de carvão vegetal dispersos na matriz do solo. Caulinita é o principal mineral da fração argila nos horizontes $A$ e $B$, seguido em abundância por gibbsita e por vermiculita com hidroxi entrecamadas. Este último argilomineral é identificado apenas nos Lh derivados de rochas basálticas da região Sul. Os teores de C total (CT) variam de 5 a $101 \mathrm{~g} \mathrm{~kg}^{-1}$ no horizonte A húmico. Carbono oxidado por via úmida com dicromato de potássio constitui, em média, $75 \%$ do CT dos horizontes A húmicos, enquanto o C não oxidável com dicromato (C-res), que inclui formas de C recalcitrantes (como carvões), contribui para os restantes $25 \%$ do CT. Os conteúdos de $C$ foram independentes da maioria das variáveis inorgânicas do solo, exceto do Al extraído com oxalato de amônio ácido (OAA), que individualmente explica $69 \%(P<0,001)$ da variabilidade de CT do horizonte A húmico. Os conteúdos de argila não foram estimadores eficazes do CTe de outras formas de Cestudadas, como também não foram: densidade do solo, $\mathrm{Al}^{3+}$ trocável, saturação por Al, capacidade de troca de cátions efetiva e outros parâmetros obtidos por extrações seletivas com OAA e ditionitocitrato-bicarbonato. Interações entre materiais orgânicos e minerais pobremente cristalinos, como indicado pelo Al extraído com OAA, apresentam-se como um dos mecanismos possíveis para proteção da matéria orgânica nesses solos.
\end{abstract}

Termos de indexação: Latossolos, solos tropicais, carbono total, carbono orgânico do solo, carvão do solo, carbono pirogênico, horizonte A húmico.

\section{INTRODUCTION}

In Umbric Ferralsols with thick epipedons (A horizon $>100 \mathrm{~cm}$ ) (UF) the content of organic matter $(\mathrm{OM})$ in deeper layers is significant. Umbric Ferralsols are commonly found in the Southeast and South of Brazil, and less frequently in the Northeast
(Ker, 1997). According to FAO-UNESCO (1971-1981) these soils cover an area of $144,000 \mathrm{~km}^{2}$ of the territory (equivalent to the State territory of Ceará). These soils characteristically have thick surface horizons, a dark color (value and chroma $\leq 4$ ) and significant organic carbon $(\mathrm{OC})$ contents, overlying the $\mathrm{Bw}$ diagnostic horizon of Latosols (Embrapa, 2006). 
The genesis and paleoenvironmental significance of UF are not completely understood. Most authors suggest they are soils relic in the landscape of a favorable climate for $\mathrm{OC}$ accumulation in the past, preserved due to several specific soil and environmental factors (Queiroz Neto \& Castro, 1974; Lepsch \& Buol, 1986; Ker 1997; Buol \& Eswaran, 2000; Calegari, 2008) such as high acidity, low-base saturation, relatively cold altitude climate, stable geomorphic surfaces and complex organomineral formations. Additionally, Silva \& Vidal Torrado (1999) suggested that the humus-rich horizons could be a result of surface addition of charred material (charcoal) that had been partially altered, decomposed into microparticles, and distributed in the soil over time by biological activity.

The presence of charcoal fragments scattered in the soil matrix suggests that in addition to other formation factors, the frequency of natural fires affected the organic matter (OM), and possibly played an important role in the pedogenesis of some of these Brazilian UFs, similarly to the mollic (chernozemic) soils in Germany (Schmidt et al., 1999) and volcanicash-rich soils in Japan (Shindo et al., 2004). These charred materials are considered resistant to organic decomposition and chemical change, and can therefore remain in soils for thousands of years (Masiello et al., 2007). However, it is accepted nowadays that the presence of oxygen and moisture cause some degradation of part of the charcoal fragments, although this is a very slow process (Bird et al., 1999; Knicker et al., 2008).

Similarly to the Terras Pretas de Índio (TPI), UFs have dark and thick surface horizons, with large OC reserves and the presence of charcoal fragments. The formation processes, chemical properties and environments of occurrence, however, are quite different. The TPI were formed mainly under human influence, with irregular vertical and horizontal distribution of OC, a high phosphorus content $(\mathrm{P})$ (200-400 $\mathrm{mg} \mathrm{kg}^{-1}$ ) and a cation exchange capacity controlled by $\mathrm{Ca}^{2+}$ and $\mathrm{Mg}^{2+}$ (Novotny et al., 2007). The UFs on the other hand are a natural phenomenon (charcoal fragments are not associated with lithic artifacts or pieces of pottery), frequently found at the top of slopes, with gradual reduction in the OC content with increasing depth and toward adjacent nearby soils, low P concentrations and exchange complex and often predominance of exchangeable $\mathrm{Al}^{3+}$ (Ker, 1997).

The study of Umbric Ferralsols with thick epipedons is particularly intersting because of the significant amount of accumulated OC (300 t/ha in the first $1 \mathrm{~m}$ ), five times higher than in other Ferralsols classes (Andrade et al., 2004) and the potential to studies of paleoenvironmental reconstruction (Calegari, 2008). In many of these polycyclic Ferralsols (Lepsch \& Buol, 1986; Calegari, 2008) past climate changes are recorded and fossil carbon (charcoal) is found. Moreover, there is little information on the supposedly stabilized OM accumulation that contributes to maintain the thick epipedons.

The aim of this study was to characterize general properties of eight UF pedons from different regions of Brazil under distinct plant physiognomy and relate them to carbon preservation in depth.

\section{MATERIAL AND METHODS}

\section{Selection of pedons}

The pedons studied are representative of three UF sets defined by Calegari (2008) (Figure 1). These groups were established based on a factor analysis of a set of 39 pedons. The properties considered in the statistical analysis were climate, altitude, relief, parent material, clay content, A horizon thickness, exchangeable $\mathrm{Al}^{3+}$, extractable $\mathrm{Fe}$ fractions in the sulfur extract, organic carbon, $\mathrm{pH}\left(\mathrm{H}_{2} \mathrm{O}\right)$, and the $\mathrm{SiO}_{2} /$ $\mathrm{Al}_{2} \mathrm{O}_{3}$ molar ratio. The groups were defined as:

Group 1: Latossolos Brunos (LB) and Latossolos Vermelhos (LV) on top surfaces of Southern Brazil, with greater $\mathrm{CO}$ and $\mathrm{Fe}_{2} \mathrm{O}_{3}$ contents and more oxidic clay mineralogy than the others;

Group 2: Latossolos Vermelho-Amarelo (LVA) and Latossolos Amarelos (LA) on old geomorphic surfaces in the Southeast, associated with mountain vegetation and climate, with intermediate $\mathrm{CO}$ values; and

Group 3: LVA and LA with thicker epipedon $(>150 \mathrm{~cm})$, found on higher surfaces of intermediate areas (peripheral depression in São Paulo and Coastal plain region in the Northeast), with the lowest CO contents and essentially kaolinitic mineralogy.

Based on this classification, eight pedons under different plant physiognomy were selected (Mixed Mountainous Ombrophylous Forest, Dense Mountainous Ombrophylous Forest, Semidecidual Mountainous Seasonal Forest, Savanna woodland, and Decidual Submountainous Seasonal Forest) (Veloso et al., 1991; IBGE, 2004a). All belong to the Atlantic Forest biome, except the Savanna woodland, which belongs to the Cerrado biome (IBGE, 2004b).

The Mixed Mountainous Ombrophylous Forest covers vast areas in Southern Brazil, between the latitudes $24^{\circ}$ and $30^{\circ} \mathrm{S}$, at 1,000 to $1,400 \mathrm{~m}$ asl (Dümig et al., 2008), and, in smaller areas, in the Southeast in fragments of the Serra do Mar and Mantiqueira (IBGE, 1992). This forest is composed of deciduous and conifer trees, among which the arboreal mass of the species Araucaria angustifolia (Bertol.) Kuntze (Paraná Pine) is predominant. The predominant climate is subtropical $(\mathrm{Cw})$, characterized by temperatures $<18^{\circ} \mathrm{C}$ in the winter and high rainfall distributed evenly throughout the year. Under this 
vegetation, two typical UFs derived from basalt of the Serra Geral Formation (Cretaceous) (representative of Group 1) were selected, one in Xanxerê-SC (LV) and the other in Guarapuava-PR (LB) (Table 1).
The Dense Mountainous Ombrophylous Forest is characterized by mild temperatures and high precipitation $(>1,200 \mathrm{~mm})$. This vegetation type was almost completely destroyed by the expansion of

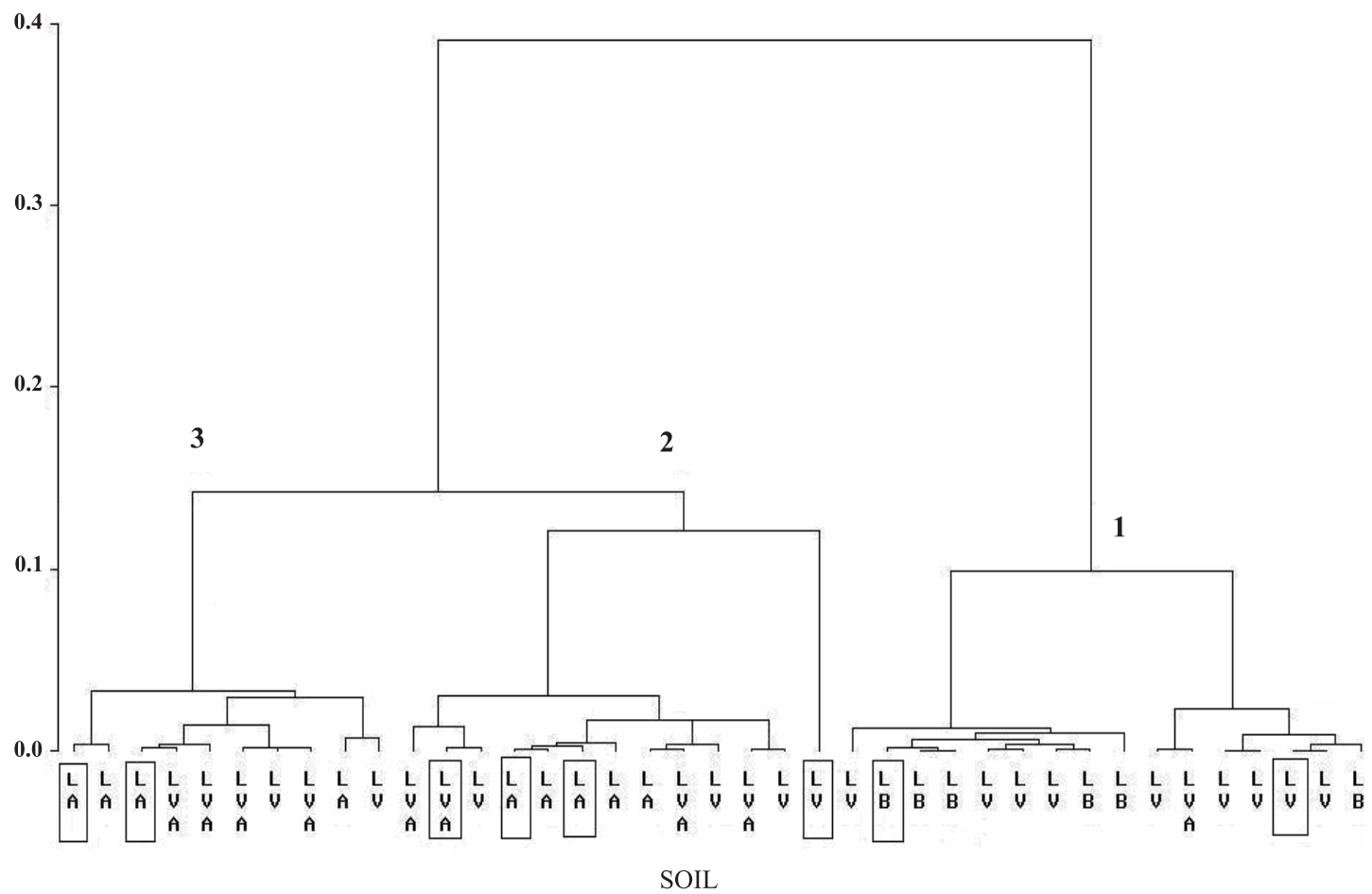

Figure 1. Hierarchical cluster analysis of the physical, chemical and environmental conditions of 39 pedons of UF. 1: Group 1; 2: Group 2 and 3: Group 3. LVA: Latossolo Vermelho-Amarelo; LA: Latossolo Amarelo; LB: Latossolo Bruno and LV: Latossolo Vermelho. Rectangles indicate the base soils selected for study.

Table 1. Vegetation, location, soil classification, altitude (m), climate and parent material of the pedon sampling areas

\begin{tabular}{|c|c|c|c|c|c|c|}
\hline Vegetation & Location & Coordinates & Soil $^{(1)}$ & Altitude & Climate $^{(2)}$ & Parent material \\
\hline \multirow{2}{*}{$\begin{array}{l}\text { Mixed Mountainous } \\
\text { Ombrophylous Forest }\end{array}$} & Xanxerê (SC) & $\begin{array}{l}26^{\circ} 52^{\prime} 44^{\prime \prime} \mathrm{S} \\
52^{\circ} 26^{\prime} 26^{\prime \prime} \mathrm{O}\end{array}$ & LVdf & $\begin{array}{c}\mathrm{m} \\
810\end{array}$ & Cfa & \multirow{2}{*}{ Basalts } \\
\hline & Guarapuava (PR) & $\begin{array}{l}25^{\circ} 21^{\prime} 09^{\prime \prime} \mathrm{S} \\
51^{\circ} 28^{\prime} 01^{\prime \prime} \mathrm{O}\end{array}$ & $\mathrm{LBw}$ & 1080 & $\mathrm{Cfb}$ & \\
\hline $\begin{array}{l}\text { Dense Mountainous } \\
\text { Ombrophylous Forest }\end{array}$ & Nova Friburgo (RJ) & $\begin{array}{l}22^{\circ} 13^{\prime} 19^{\prime \prime} \mathrm{S} \\
42^{\circ} 30^{\prime} 23^{\prime \prime} \mathrm{O}\end{array}$ & LAd & 850 & $\mathrm{Cwb}$ & Gneiss \\
\hline \multirow{2}{*}{$\begin{array}{l}\text { Semidecidual Mountainous } \\
\text { Seasonal Forest }\end{array}$} & Machado (MG) & $\begin{array}{l}21^{\circ} 38^{\prime} 07^{\prime \prime} \mathrm{S} \\
45^{\circ} 56^{\prime} 16^{\prime \prime} \mathrm{O}\end{array}$ & LVAd & 1155 & Cwb & Gneiss-Migmatite \\
\hline & Manhuaçu (MG) & $\begin{array}{l}20^{\circ} 15^{\prime} 04^{\prime \prime} \mathrm{S} \\
42^{\circ} 10^{\prime} 36^{\prime \prime} \mathrm{O}\end{array}$ & LAd & 895 & Cwa & Charnokites \\
\hline $\begin{array}{l}\text { Decidual Submountainous } \\
\text { Seasonal Forest }\end{array}$ & Paudalho (PE) & $\begin{array}{l}07^{\circ} 51^{\prime} 41^{\prime \prime} \mathrm{S} \\
35^{\circ} 12^{\prime} 21^{\prime \prime} \mathrm{O}\end{array}$ & LAd & 180 & $\mathrm{As}^{\prime}$ & Sediments ${ }^{(3)}$ \\
\hline \multirow{2}{*}{ Savanna woodland } & Campinas (SP) & $\begin{array}{l}23^{\circ} 00^{\prime} 58^{\prime \prime} \mathrm{S} \\
45^{\circ} 56^{\prime} 15^{\prime \prime} \mathrm{O}\end{array}$ & LAd & 660 & Cwa & Sediments $^{(3)}$ \\
\hline & Salinas (MG) & $\begin{array}{l}16^{\circ} 16^{\prime} 16^{\prime \prime} \mathrm{S} \\
42^{\circ} 58^{\prime} 50^{\prime \prime} \mathrm{O}\end{array}$ & $\mathrm{LVd}$ & 910 & $\mathrm{Aw}$ & Phyllite-Schist \\
\hline
\end{tabular}

(1) LVAd: Latossolo Vermelho-Amarelo distrófico; LAd: Latossolo Amarelo distrófico; LBw: Latossolo Bruno ácrico, LVdf: Latossolo Vermelho distroférrico and LVd: Latossolo Vermelho distrófico. ${ }^{(2)}$ Köppen climate classification. ${ }^{(3)}$ Clayey-sandy Sediments. 
human occupation (agriculture and deforestation) in the last century and only small patches remain in the Northeast and Southeast regions. One area still under native vegetation was chosen in Nova FriburgoRJ, where a pedon (LA) was collected and described as belonging to Group 2.

Under the Semidecidual Mountainous Seasonal Forest, two Ferralsols were selected (Group 2), a pedon in Machado-MG (LVA) and another in Manhuaçu-MG (LA) derived from highly weathered metamorphic rocks (Precambrian gneiss or charnokitos). Under the Decidual Submountainous Seasonal Forest, which covers a narrow area in the Northeast (NE) between the humid forest and the Caatinga (dry forest in the Northeast), a Ferralsol of Group 3 was selected (LA in Paudalho-PE) derived from sedimentary rocks and sediments of the Tertiary period (Barreiras Formation).

The Cerrado biome covers about 2 million $\mathrm{km}^{2}$ of the national territory and is characterized by welldefined wet and dry seasons. The vegetation, less dense than the preceding vegetation type, is mostly composed of relatively short shrubs and trees (5-15 m) with twisted trunks and deep roots, and grasses. The occurrence of natural fires in this Brazilian ecosystem is common, particularly in the dry season (AprilSeptember) (Roscoe et al., 2001). Two pedons were chosen under Savanna woodland, a LA in CampinasSP (Group 3) and a LV in Salinas-MG (Group 2).

\section{Study areas and sampling}

The location of the pedons, vegetation types, climate of the studied sites, parent material and soil classification up to the $3^{\text {rd }}$ category level according to SiBCS (Embrapa, 2006) are summarized in table 1 and figure 2 . The pedons are distributed between $7^{\circ}$ and $27^{\circ}$ southern latitude. Mean annual temperatures and rainfall of the selected sites are shown in figure 3.

Trenches were dug (depth $200 \mathrm{~cm}$ ) on the top or upper part of slopes and the pedons were morphologically described according to Santos et al. (2005). Deformed samples were collected from all horizons and air-dried, crumbled and sieved (2 $\mathrm{mm}$ mesh) to obtain the air-dried fine earth (ADFE). Fragments $>1 \mathrm{~cm}$ of rock (gravel and pebbles), charcoal and roots were removed. The ADFE represents $96-100 \%$ of the soil mass. Additional samples were collected with an auger to a depth of $300 \mathrm{~cm}$, in cases where the epipedons were thicker than $150 \mathrm{~cm}$ (Embrapa, 2006).

\section{Mineralogical, physical and chemical properties of UFs}

The mineralogical analysis of the clay fractions were performed by means of $\mathrm{X}$ ray diffractometry (XRD), using $\mathrm{CuK} \alpha$ radiation in samples of $\mathrm{A}$ and $\mathrm{Bw}$ horizons of all pedons but from Guarapuava-PR, in which the clay mineralogy was detailed by Ghidin et al. (2006a). The samples were previously treated with

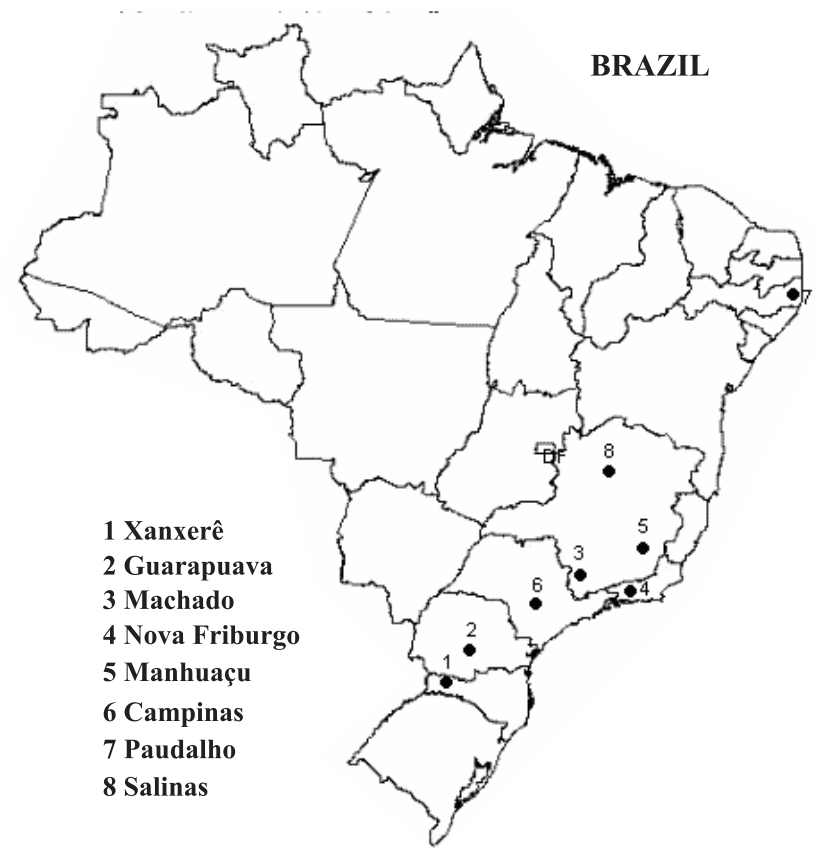

Figure 2. Location of the pedons studied in Brazil.

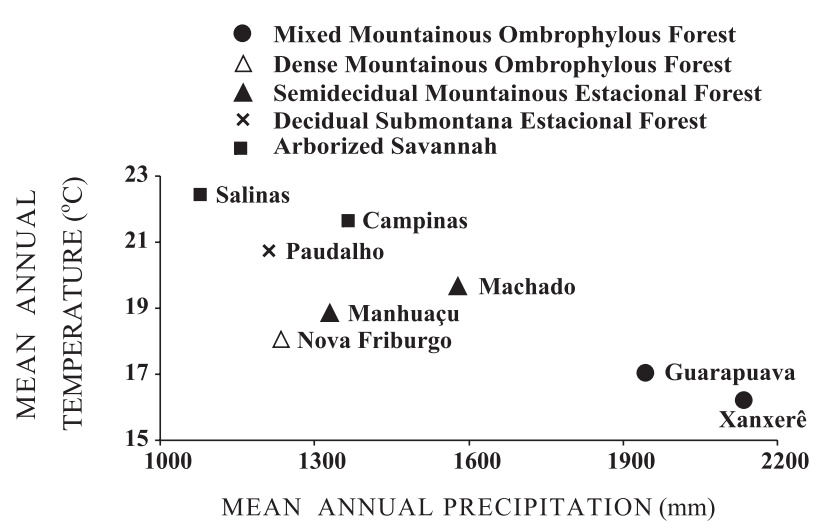

Figure 3. Mean Annual precipitation and temperatures of the studied locations. Source: http://www.bdclima.cnpm.embrapa.br/ resultados/index.php (access on May 20, 2009).

hydrogen peroxide $\left(\mathrm{H}_{2} \mathrm{O}_{2}\right)$ and dithionite-citratebicarbonate (DCB) to remove $\mathrm{OM}$ and iron oxides, respectively (Jackson, 1956), and oriented on glass slides. The potassium-saturated slides were irradiated at room temperature $\left(25^{\circ} \mathrm{C}\right)$ and afterwards heated to 350 and $500{ }^{\circ} \mathrm{C}$, whereas those saturated with $\mathrm{Mg}$ glycerol were irradiated at room temperature only. The XRD patterns were obtained by a Phillips diffractometer model PW 3710 at the Research Center of Geochemistry and Geophysics of the Lithosphere (NUPEGEL/USP), with a span of 3 to $65^{\circ} 2 \theta$, and interpreted according to Brown \& Brindley (1980).

The sand mineralogy of UF was not identified in this study because it was described in other papers. The pedons studied were selected based on a database 
that contain only UF analyzed and classified in surveys, theses, dissertations and articles. These studies reveal easily alterable quantities of minerals in the sand fraction within the limits established for the order of Latossolos (Embrapa, 2006).

The particle size analysis of ADFE was performed after dispersion with $0.01 \mathrm{~mol} \mathrm{~L}^{-1} \mathrm{NaOH}$ solution. Fractions of coarse sand $(0.2-2.0 \mathrm{~mm})$ and fine sand ( 0.053 to $0.2 \mathrm{~mm}$ ) were measured by gravimetry, while the clay fraction $(<0.002 \mathrm{~mm})$ was measured by a hydrometer. The silt fraction (0.002 to $0.053 \mathrm{~mm}$ ) calculated as the difference (Embrapa, 1997). Soil bulk density (BD) was determined by the amount of dry soil (grams) contained in $100 \mathrm{~cm}^{3}$ cylinders collected from the field in triplicate (Embrapa, 1997).

Soil $\mathrm{pH}$ was measured in $\mathrm{H}_{2} \mathrm{O}$ and $\mathrm{KCl} 1 \mathrm{~mol} \mathrm{~L}^{-1}$ solutions (ratio soil:solution 1:2.5). The cation exchange capacity (CEC) (in $\mathrm{cmol}_{\mathrm{c}} \mathrm{kg}^{-1}$ ) was calculated through the sum of exchangeable cations $\mathrm{Ca}^{2+}, \mathrm{Mg}^{2+}$ and $\mathrm{Al}^{3+}$ extracted with solution of $\mathrm{KCl} 1 \mathrm{~mol} \mathrm{~L}^{-1}$, of $\mathrm{K}^{+}$and $\mathrm{Na}^{+}$extracted with a solution of $0.05 \mathrm{~mol} \mathrm{~L}^{-1}$ $\mathrm{HCl}$, and of $\mathrm{H}+\mathrm{Al}$, extracted with buffer solution of calcium acetate $\mathrm{pH}$ 7.0. From these values, the effective CEC, base saturation (V value) and aluminum saturation (m \%) were also calculated.

For the soil classification according to SiBCS (Embrapa, 2006), $1 \mathrm{~g}$ of ADFE was digested with $20 \mathrm{~mL}$ of $\mathrm{H}_{2} \mathrm{SO}_{4} 1: 1$ and the contents of $\mathrm{SiO}_{2}, \mathrm{Al}_{2} \mathrm{O}_{3}$, $\mathrm{Fe}_{2} \mathrm{O}_{3}$, and $\mathrm{TiO}_{2}$ were determined in the extract of sulfuric acid (Embrapa, 1997). From these concentrations, molecular ratios Ki and $\mathrm{Kr}$ (Resende \& Santana, 1988) were calculated, which are also used as weathering indexes.

The forms of poorly-crystallized iron and aluminum $\left(\mathrm{Al}_{0}\right.$ and $\mathrm{Fe}_{\mathrm{o}}$, respectively) were extracted with solution of acid ammonium oxalate (AAO) (Schwertmann \& Taylor, 1989) and free iron and aluminum $\left(\mathrm{Al}_{\mathrm{d}}\right.$ and $\left.\mathrm{Fe}_{\mathrm{d}}\right)$ were extracted with $\mathrm{DCB}$ solution (Coffin, 1963). The $\mathrm{Al}$ and $\mathrm{Fe}$ contents in the extracts were determined by atomic absorption spectrophotometry.

\section{Carbon and nitrogen}

Contents of total carbon (TC) and total nitrogen (TN) were determined in duplicate by dry combustion $\left(950^{\circ} \mathrm{C}\right)$ in an elemental analyzer (NCS Soil Analyzer Flash EA 1112), while organic carbon (OC) contents were analyzed by wet oxidation with potassium dichromate $\left(\mathrm{K}_{2} \mathrm{Cr}_{2} \mathrm{O}_{7}\right) 0.4 \mathrm{~mol} \mathrm{~L}^{-1}$ (Embrapa, 1997), in triplicate. The labile carbon (C-labile), which contains more easily decomposable organic compounds, such as the microbial materials, was determined, in triplicate, by oxidation with potassium permanganate solution of $0.2 \mathrm{~mol} \mathrm{~L}^{-1}$ (Blair et al., 1995). ADFE samples were ground and sieved $(0.2 \mathrm{~mm}$ mesh) and used in the analysis of these carbon fractions.
The difference between TC and OC contents was denominated oxidation-resistant carbon (C-res). This fraction presumably includes pyrogenic $\mathrm{C}$ (black carbon), which has high resistance to chemical and biological decomposition due to its formation/ transformation by fire (Knicker et al., 2007), besides carbon forms strongly associated with clay.

\section{Amounting and dating of charcoals}

About $5 \mathrm{~kg}$ of soil were collected at different depths in three pedons (LAd in Campinas-SP and in Manhuaçu-MG and LVd in Salinas-MG) to determine the mass of charcoal. Soil samples were weighed and then sieved (1 mm mesh), and the charcoal fragments retained on the sieve were collected with tweezers, rinsed with water, dried and weighed. Charcoal fragments arranged in two distinct rows $(60-75 \mathrm{~cm}$ and 200-210 cm) of LVd of Salinas-MG were dated by ${ }^{14} \mathrm{C}$. This dating was performed using mass spectrometry coupled to a particle accelerator at the Center for Applied Isotope Studies at the University of Georgia, USA. The ${ }^{14} \mathrm{C}$ age was expressed in years BP (before present), normalized to - $25 \%$ (PDB) and calibrated to the present, year 1950.

\section{Statistical analysis}

Analyses of linear correlation were performed between soil C content (TC, OC, C-res and C-labile) and between these and some UF properties (chemical and physical properties) using STATISTICA 5.0 software, to study the relationship of these properties with carbon preservation.

\section{RESUFTS AND DISCUSSION}

\section{Soil position in the landscape}

As suggested by the position in the landscape (top or upper third of the slope) morphology and Ti/Zr ratio (Calegari, 2008), the colluvial process was not the primary factor causing the thick epipedons in the pedons studied. Evidence of this process is found in the UFs described in Nova Friburgo-RJ and MachadoMG, both located in the upper third of slopes in mountainous areas with declivity $>25 \%$. In the first, the A2 and A3 horizons have slightly darker colors than the overlying horizon, which suggests colluvial deposition, while in Machado-MG, a recent $10 \mathrm{~cm}$ thick deposit of reworked material (colluvium) was clearly identified in the upper epipedon. However, the ratio $\mathrm{Ti} / \mathrm{Zr}$ of these and other UFs reported by Calegari (2008), shows that the formation and development (thickening) of the A horizon of pedons occurred after colluvial deposition.

The situation of these pedons in the landscape is quite different from the Ferralsols found in middle and lower slopes, where the epipedon thickening is clearly due to the accumulation of reworked material derived from upstream positions (Silva et al., 2007; Calegari, 2008). 


\section{Soil morphology}

The Ferralsols studied are very deep, well to markedly drained and have a dark and OC-rich A horizons in depth, all classified as humic by the SiBCS (Embrapa, 2006). The epipedon thickness of the selected pedons ranged from 100 to $220 \mathrm{~cm}$, indicating huge OC reserves (Calegari, 2008). The LAd described in Campinas-SP has the thickest A horizon $(220 \mathrm{~cm})$ of all studied pedons.

Some of the epipedons have conspicuous morphological features, such as: (a) randomly distributed brownish spots (Campinas-SP) and; (b) clearly formed vertical channels (pedotubules) with a diameter of at least $2 \mathrm{~cm}$ in and variable length (Machado-MG, Salinas-MG, Xanxerê-SC and Guarapuava-PR). These Pedotubules are filled with small to very small granular aggregates, well-rounded and reddish or dark materials originating from overlying horizons. It was not possible to identify the organisms responsible for these features; however, they seem to be a result from the intense activity of arthropods (mainly termites and ants). The occurrence of biological channels in Brazilian Ferralsols, particularly those with high clay content that seem to preserve these features for a long period, is widely documented in the literature (Silva \& Vidal-Torrado, 1999; Schaefer, 2001; Zinn et al., 2007).

Clear lines of macroscopic charcoal fragments were identified in the pedons located in Campinas-SP (between 65-80 and 95-110 $\mathrm{cm}$ ) and in Salinas-MG (between 60-75 and 200-210 cm), both under Cerrado vegetation. The charcoal lines of the LVd of SalinasMG were dated by ${ }^{14} \mathrm{C}$ to ages of $1,660 \pm 73(60-75 \mathrm{~cm})$ and $7,895 \pm 59(200-210 \mathrm{~cm})$ years Cal. AP. These ages are consistent with those found by Gouveia et al. (1999) and Silva \& Vidal-Torrado (1999) in soils from the southeastern region and show a period of fires associated with drier climatic periods in the Middle Holocene (Pessenda et al., 1996, 2004).

Once most of the charred material is deposited on the surface, the occurrence of charcoal lines in depth indicates that, similarly to the formation of stonelines, a selective vertical transport through the soil fauna of materials from deeper to surface horizons (pedoturbation) occurred for a considerable period of time (Gouveia et al., 1999).

Based on the ages obtained by ${ }^{14} \mathrm{C}$ dating of charcoal lines of the LVd of Salinas-MG, the mobilization rates in the pedon were calculated, which were 0.41 and $0.26 \mathrm{~mm}$ year ${ }^{-1}$, for the lines of $60-75 \mathrm{~cm}$ and 200 $210 \mathrm{~cm}$ respectively. These charcoal mobilization rates are in agreement with those found for other Ferralsols classes by Miklós (1992) and Gouveia et al. (1999) in São Paulo. The charcoal mass in the soils at different depths (Table 2) ranged from 7.0 to $35.3 \mathrm{~g}$ in the pedons under Cerrado vegetation (Campinas, SP and Salinas-MG - Savanna woodland) and from 1.3 to $1.6 \mathrm{~g}$ in the LAd of Machuaçu-MG, under
Semideciduous Mountainous Seasonal Forest. The highest charcoal concentration in soils under Cerrado is due, presumably, to the greater frequency of fires in this ecosystem, compared to the others (Czimczik $\&$ Masiello, 2007). These charcoal contents are within the ranges documented by Silva \& Vidal Torrado (1999) (0.5 to $125.7 \mathrm{~g}$ ) and Gouveia et al. (1999) (up to $121.9 \mathrm{~g}$ ) for Ferralsols.

There were no charcoal fragments in pedons described in the South (Xanxerê-SC and Guarapuava -PR), located in areas under higher rainfall volumes. This may be due to: (a) absence of regular and intense fires, (b) vegetation predominantly of grasses in the past and/or (c) erosion of burned residues. In the other pedons, except for the LVAd of Machado-MG, charcoal fragments were found in small numbers, scattered on the ground.

All pedons have dark colors near the surface, gradually transitioning to yellow, red, yellowish red or brown subsurface layers. The Latossolo Bruno ácrico $(\mathrm{LBw})$ described in Guarapuava-PR, however, deserves special emphasis due to its distinct polychrome. This Ferralsol shows dark colors in the humic A horizon (2.5YR 3/1 and 5YR 3/3), brownish tone in an intermediate layer $(120-140 \mathrm{~cm})$ and red hue (2.5YR 3/6) at the trench base (180-200 cm). The brownish overlying the red layer indicates goethite formation (xanthization process) and a record of bioclimatic changes (Schwertmann, 1971). Supposedly it represents a milestone in the transition from a dry and warm to a cooler and wetter climate, where milder temperatures, more rainfall and $\mathrm{OM}$ accumulation in the soil favor the formation of goethite in detriment of hematite (Kämpf \& Schwertmann, 1983). Ghidin et al. (2006a) documented the predominance of goethite (Gt) over hematite $(\mathrm{Hm})$ in the transitional horizon $\mathrm{AB}(90-120 \mathrm{~cm}$ ) of this pedon (Table 6). The signature of $\delta^{13} \mathrm{C}$ of the soil OM in this pedon reported by Calegari (2008) suggests a change of vegetation of the photosynthetic pathway from $\mathrm{C}_{4}$ to $\mathrm{C}_{3}$ (from - $17 \%$ to $-24 \%$ ) during the Holocene. Moreover, this pedoenvironment with mild climate, high precipitation regularly distributed throughout the year, and rich

Table 2. Charcoal mass in $\mathrm{g} 10 \mathrm{~kg}^{-1} \mathrm{UF}$ soil from different depths

\begin{tabular}{lccc}
\hline Location & Soil & Depth & Charcoal \\
\hline \multirow{2}{*}{ Manhuaçu (MG) } & LAd & $60-80$ & $\mathrm{~g} 10 \mathrm{~kg}^{-1}$ soil \\
& & $100-120$ & 1.6 \\
Campinas (SP) & LAd & $80-100$ & 1.3 \\
& & $160-180$ & 10.0 \\
& & $200-220$ & 9.4 \\
Salinas (MG) & LVd & $0-30$ & 10.3 \\
& & $60-75$ & 12.3 \\
& & $160-210$ & 35.3 \\
& & & 7.0 \\
\hline
\end{tabular}


in OM supports the formation of goethites in the LBw (Kämpf \& Schwertmann, 1983).

Compared with the LBw of Guarapuava-PR, xanthization is much less significant in the LVdf of Xanxerê-SC (about $230 \mathrm{~km}$ southwest of the LBw). Although these soils are derived from the same parent material (basalt), the LVdf has higher Fe contents as evidenced by digestion with sulfuric acid and extraction with DCB (Table 6). The reduced significance of the xanthization process in the LVdf of Xanxerê-SC may be related to (a) richer pedon in iron oxides, (b) better soil drainage, reducing water activity, (c) unfavorable local microclimate and/or (d) no significant paleoenvironmental change in the past, including the Holocene.

\section{Physical properties}

The UF studied vary from clayey to very clayey, a result of intense desilication (Buol \& Eswaran, 2000) that preceded $\mathrm{OC}$ accumulation in the soil. The clay content ranged from 314 to $704 \mathrm{~g} \mathrm{~kg}^{-1}$ in the epipedon and these values tend to increase with depth (Table 3). Except for pedons in the South (LVdf and LBw), silt contents are little significant and the distribution among horizons irregular (Table 3).

The silt content in the LVdf of Xanxerê-SC and in the LBw of Guarapuava-PR varied from 21 to $34 \%$ among horizons, and was higher than of other Ferralsol classes also developed from basic effusive rocks (basalts) in the South (Ghidin et al., 2006b). The high stability of microaggregates, resulting from the cementing action of $\mathrm{OM}$ and $\mathrm{Fe}$ and $\mathrm{Al}$ oxides made the complete dispersion of clay minerals by the traditional granulometric methods of analysis impossible, particularly in clayey soils (Donagemma et al., 2003). Although the nature of the silt fraction has not been investigated, it is supposed that, along with it, there are also very stable still preserved claymicroaggregates, which resulted in an overestimation of the content of this fraction (silt) in these Ferralsols. Nevertheless, the silt/clay ratio was low $(<0.6)$, and tended to decrease with depth, corroborating the idea of intense weathering and successive pedogenesis cycles, besides indicating a strong predominance of secondary minerals.

Compared to clay, the sand content was low, particularly in UFs described in Xanxerê-SC and Guarapuava-PR, where the parent material had undergone significant changes (Calegari, 2008) and contained low amounts of weathering-resistant minerals, e.g., quartz. In the sand fraction, the contents of fine sand are predominant over those the coarse sand fraction in most UFs studied (Table 3).

In general, the bulk density (BD) in the humic epipedons was lower than $1.0 \mathrm{t} \mathrm{m}^{-3}$, remaining constant or increasing slightly with depth (Table 3), while the OM content decreased. The oscillation in BD between horizons may be associated with soil compaction on the soil surface or variations in texture and/or soil structure in depth (Calegari, 2008). Ghidin et al. (2006b) studied the influence of clay mineralogy on the physical properties of the LBw of GuarapuavaPR. These authors observed that the contents of kaolinite and gibbsite were significantly correlated $(\mathrm{r}$ $=0.92 * *$ and $-0.93^{* *}$, respectively) with the $\mathrm{BD}$ of subsurface horizons.

\section{Chemical properties}

Regardless of the vegetation type or the parent material, all Ferralsols studied were highly acidic, dystrophic and highly $\mathrm{Al}^{3+}$ saturated. The water $\mathrm{pH}$ ranged from 4.1 to 5.6 and exceeded the $\mathrm{pH}$ in $\mathrm{KCl}$ in all horizons, except in the Bw horizon of the LBw of Guarapuava-PR, demonstrating that despite the intense weathering, negative charges still predominate in the exchange complex (Table 4).

As suggested by the significant precipitation ( $>1,000 \mathrm{~mm}$, Figure 3), the long exposure time and landscape position, these soils are poor in bases. Contents of exchangeable $\mathrm{Na}^{+}$were virtually nonexistent, whereas cations $\mathrm{K}^{+}, \mathrm{Ca}^{2+}$ and $\mathrm{Mg}^{2}$ had slightly larger values in the epipedon than the other subsurface horizons, which is typical of nutrient cycling by vegetation in highly leached soils (Simas et al., 2005) (Table 4). In the humic LVd, which is currently located in a transition area between the Cerrado and Caatinga vegetation (Northern Minas Gerais state), under sub-humid climate (Aw), the $\mathrm{Na}$ contents were much higher $\left(0.52-0.58 \mathrm{cmol}_{\mathrm{c}} \mathrm{kg}^{-1}\right)$, possibly due to a drier climate, resulting in less $\mathrm{Na}$ leaching.

The CEC decreased sharply with depth in all soils, along with the carbon contents. The $\mathrm{Al}^{3+}$ saturation ( $\mathrm{m} \%$ ) was high in all pedons, mainly in the humic epipedon, probably due to the effect of partial destabilization of clay minerals by the acidifying action of $\mathrm{OM}$, resulting in $\mathrm{Al}^{3+}$ release. A similar geochemical behavior was reported by Simas et al. (2005), Schaefer et al. (2002), Silva \& Vidal Torrado (1999) and Volkoff et al. (1984) for Brazilian Ferralsols and other soils in mountainous areas.

\section{Carbon and nitrogen}

As indicated by the low soil pH, carbonates are absent in these soils and all total carbon (TC) determined was organic. The TC contents determined by dry combustion ranged from 5 to $101 \mathrm{~g} \mathrm{~kg}^{-1}$ between horizons and decreased gradually with depth in the pedons. This trend was also observed in contents of total nitrogen (TN) and of oxidizable $\mathrm{C}$ fractions (OC and C-labile) (Table 5).

Total $\mathrm{C}$ contents at a depth of $1 \mathrm{~m}$ in the pedons studied were $>15 \mathrm{~g} \mathrm{~kg}^{-1}$, indicating large carbon stocks in the subsurface horizons (Andrade et al., 2004; Dick et al., 2005). The lowest TC and TN contents in the humic epipedon were recorded in the LAd of 
Table 3. Some physical and morphological properties of UF pedons studied

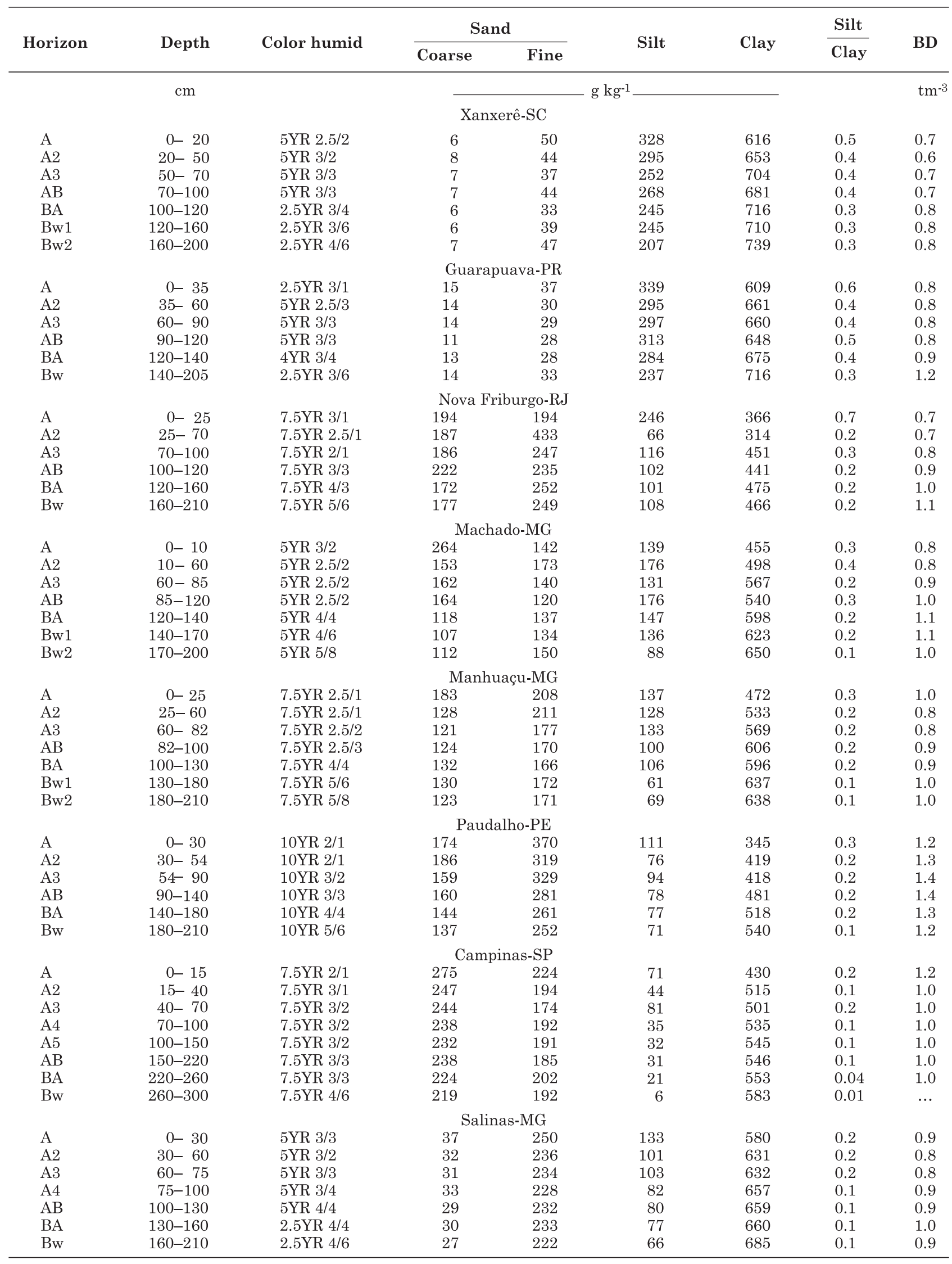


Table 4. Some chemical properties of UF pedons studied

\begin{tabular}{|c|c|c|c|c|c|c|c|c|c|c|c|}
\hline \multirow{2}{*}{ Horizon } & \multirow{2}{*}{ Depth } & \multicolumn{2}{|c|}{ pH (1:2.5) } & \multirow{2}{*}{$\mathbf{K}^{+}$} & \multirow{2}{*}{$\mathrm{Na}^{+}$} & \multirow{2}{*}{$\mathrm{Ca}^{2+}$} & \multirow{2}{*}{$\mathrm{Mg}^{2+}$} & \multirow{2}{*}{$\mathrm{Al}^{3+}$} & \multirow{2}{*}{$\mathbf{H}^{+}$} & \multirow{2}{*}{$\mathrm{CEC}^{(1)}$} & \multirow{2}{*}{$\mathrm{m}^{(2)}$} \\
\hline & & $\mathrm{H}_{2} \mathrm{O}$ & $\mathrm{KCl}$ & & & & & & & & \\
\hline & $\mathrm{cm}$ & & & & & & $\mathrm{cmol}_{\mathrm{c}} \mathrm{kg}^{-}$ & & & & $\%$ \\
\hline & & & & & Xans & $\hat{e}-\mathrm{SC}$ & & & & & \\
\hline A & $0-20$ & 4.1 & 3.8 & 0.15 & 0.02 & 0.50 & 0.30 & 6.68 & 7.23 & 14.88 & 87 \\
\hline A2 & $20-50$ & 4.2 & 3.8 & 0.07 & 0.03 & 0.11 & 0.07 & 6.14 & 5.40 & 11.82 & 96 \\
\hline A3 & $50-70$ & 4.3 & 3.9 & 0.02 & 0.02 & 0.09 & 0.06 & 5.16 & 3.78 & 9.13 & 97 \\
\hline $\mathrm{AB}$ & $70-100$ & 4.4 & 3.9 & 0.01 & 0.00 & 0.06 & 0.04 & 4.76 & 3.37 & 8.25 & 98 \\
\hline $\mathrm{BA}$ & $100-120$ & 4.5 & 4.0 & 0.00 & 0.00 & 0.06 & 0.04 & 3.88 & 3.23 & 7.21 & 97 \\
\hline Bw1 & $120-160$ & 4.4 & 4.1 & 0.00 & 0.00 & 0.06 & 0.03 & 2.38 & 2.77 & 5.24 & 96 \\
\hline Bw2 & $160-200$ & 4.4 & 4.2 & 0.00 & 0.00 & 0.10 & 0.09 & 1.32 & 2.15 & 3.66 & 87 \\
\hline & & & & & Guarar & Iva-PR & & & & & \\
\hline A & $0-35$ & 4.6 & 4.1 & 0.11 & 0.00 & 0.41 & 0.56 & 2.03 & 6.53 & 9.65 & 65 \\
\hline $\mathrm{A} 2$ & $35-60$ & 4.9 & 4.2 & 0.02 & 0.02 & 0.06 & 0.79 & 1.17 & 4.56 & 6.61 & 57 \\
\hline A3 & $60-90$ & 4.9 & 4.3 & 0.01 & 0.02 & 0.00 & 0.54 & 0.63 & 4.41 & 5.61 & 53 \\
\hline $\mathrm{AB}$ & $90-120$ & 5.0 & 4.6 & 0.03 & 0.02 & 0.00 & 0.23 & 0.20 & 4.03 & 4.51 & 42 \\
\hline BA & $120-140$ & 5.4 & 5.1 & 0.34 & 0.03 & 0.00 & 0.02 & 0.06 & 2.80 & 3.26 & 13 \\
\hline $\mathrm{Bw}$ & $140-205$ & 5.4 & 5.4 & 0.21 & 0.02 & 0.01 & 0.03 & 0.07 & 1.87 & 2.21 & 21 \\
\hline & & & & & Nova $\mathrm{Fr}$ & Irgo-RJ & & & & & \\
\hline $\mathrm{A}$ & $0-25$ & 4.9 & 4.3 & 0.03 & 0.03 & 0.25 & 0.15 & 1.91 & 7.80 & 10.16 & 81 \\
\hline $\mathrm{A} 2$ & $25-70$ & 5.4 & 4.5 & 0.01 & 0.02 & 0.02 & 0.02 & 1.18 & 7.97 & 9.22 & 94 \\
\hline A3 & $70-100$ & 5.6 & 4.5 & 0.12 & 0.01 & 0.01 & 0.01 & 0.99 & 3.69 & 4.83 & 87 \\
\hline $\mathrm{AB}$ & $100-120$ & 5.4 & 4.5 & 0.04 & 0.01 & 0.01 & 0.01 & 0.82 & 2.40 & 3.29 & 93 \\
\hline $\mathrm{BA}$ & $120-160$ & 5.5 & 4.5 & 0.06 & 0.00 & 0.02 & 0.01 & 0.59 & 1.73 & 2.40 & 88 \\
\hline $\mathrm{Bw}$ & $160-210$ & 5.5 & 4.6 & 0.12 & 0.01 & 0.01 & 0.01 & 0.45 & 1.54 & 2.14 & 76 \\
\hline & & & & & Mach & o-MG & & & & & \\
\hline A & $0-10$ & 4.2 & 4.1 & 0.14 & 0.03 & 0.12 & 0.09 & 2.88 & 4.93 & 8.19 & 88 \\
\hline $\mathrm{A} 2$ & $10-60$ & 4.7 & 4.3 & 0.03 & 0.03 & 0.04 & 0.03 & 2.43 & 5.49 & 8.05 & 95 \\
\hline A3 & $60-85$ & 5.0 & 4.3 & 0.02 & 0.01 & 0.03 & 0.01 & 2.48 & 4.93 & 7.47 & 97 \\
\hline $\mathrm{AB}$ & $85-120$ & 5.0 & 4.3 & 0.01 & 0.01 & 0.03 & 0.01 & 2.19 & 4.64 & 6.89 & 97 \\
\hline $\mathrm{BA}$ & $120-140$ & 4.9 & 4.3 & 0.01 & 0.01 & 0.03 & 0.01 & 1.74 & 2.73 & 4.53 & 97 \\
\hline Bw1 & $140-170$ & 5.5 & 4.3 & 0.01 & 0.01 & 0.03 & 0.01 & 1.17 & 1.83 & 3.06 & 95 \\
\hline Bw2 & $170-200$ & 4.2 & 4.1 & 0.02 & 0.01 & 0.03 & 0.01 & 048 & 1.67 & 2.22 & 88 \\
\hline & & & & & Manh & $\mathrm{u}-\mathrm{MG}$ & & & & & \\
\hline A & $0-25$ & 4.3 & 4.0 & 0.12 & 0.02 & 0.50 & 0.40 & 2.69 & 6.41 & 10.13 & 72 \\
\hline $\mathrm{A} 2$ & $25-60$ & 4.3 & 4.1 & 0.03 & 0.01 & 0.16 & 0.11 & 2.85 & 5.18 & 8.35 & 90 \\
\hline A3 & $60-82$ & 4.7 & 4.2 & 0.03 & 0.01 & 0.08 & 0.07 & 1.69 & 4.68 & 6.55 & 90 \\
\hline $\mathrm{AB}$ & $82-100$ & 4.9 & 4.2 & 0.11 & 0.01 & 0.06 & 0.06 & 1.54 & 4.05 & 5.83 & 87 \\
\hline $\mathrm{BA}$ & $100-130$ & 5.0 & 4.3 & 0.03 & 0.01 & 0.05 & 0.02 & 1.49 & 3.35 & 4.95 & 93 \\
\hline Bw1 & $130-180$ & 5.3 & 4.6 & 0.02 & 0.01 & 0.05 & 0.01 & 0.30 & 1.68 & 2.07 & 77 \\
\hline Bw2 & $180-210$ & 5.6 & 5.3 & 0.10 & 0.05 & 0.04 & 0.03 & 0.03 & 1.30 & 1.55 & 12 \\
\hline & & & & & Paud & $0-\mathrm{PE}$ & & & & & \\
\hline $\mathrm{A}$ & $0-30$ & 4.5 & 4.0 & 0.21 & 0.04 & 2.68 & 0.99 & 0.95 & 3.60 & 8.46 & 20 \\
\hline $\mathrm{A} 2$ & $30-54$ & 4.4 & 3.9 & 0.15 & 0.04 & 0.93 & 0.30 & 1.87 & 2.90 & 6.18 & 57 \\
\hline A3 & $54-90$ & 4.6 & 3.9 & 0.04 & 0.04 & 0.94 & 0.27 & 1.53 & 2.39 & 5.21 & 54 \\
\hline $\mathrm{AB}$ & $90-140$ & 4.5 & 3.9 & 0.00 & 0.03 & 1.01 & 0.30 & 1.12 & 1.34 & 3.80 & 45 \\
\hline BA & $140-180$ & 4.4 & 3.9 & 0.00 & 0.03 & 0.82 & 0.27 & 1.07 & 0.91 & 3.09 & 49 \\
\hline Bw & $180-210$ & 4.5 & 4.0 & 0.00 & 0.04 & 0.91 & 0.36 & 0.58 & 0.94 & 2.84 & 31 \\
\hline & & & & & Camp & as-SP & & & & & \\
\hline A & $0-15$ & 4.9 & 4.2 & 0.10 & 0.02 & 0.29 & 0.15 & 1.94 & 4.14 & 6.64 & 78 \\
\hline $\mathrm{A} 2$ & $15-40$ & 4.8 & 4.2 & 0.03 & 0.01 & 0.06 & 0.03 & 1.84 & 3.17 & 5.13 & 94 \\
\hline A3 & $40-70$ & 4.8 & 4.2 & 0.02 & 0.01 & 0.04 & 0.02 & 2.42 & 3.07 & 5.57 & 97 \\
\hline $\mathrm{A} 4$ & $70-100$ & 4.9 & 4.2 & 0.05 & 0.01 & 0.05 & 0.01 & 1.98 & 2.94 & 5.04 & 94 \\
\hline A5 & $100-150$ & 5.1 & 2.2 & 0.02 & 0.01 & 0.08 & 0.01 & 1.66 & 3.19 & 4.97 & 93 \\
\hline $\mathrm{AB}$ & $150-220$ & 5.3 & 4.2 & 0.01 & 0.02 & 0.02 & 0.01 & 1.41 & 2.44 & 3.91 & 96 \\
\hline BA & $220-260$ & 5.2 & 4.2 & 0.03 & 0.01 & 0.02 & 0.01 & 1.23 & 2.53 & 3.83 & 94 \\
\hline $\mathrm{Bw}$ & $260-300$ & 5.6 & 4.6 & 0.01 & 0.01 & 0.01 & 0.01 & 0.28 & 1.19 & 1.51 & 87 \\
\hline & & & & & Salir & $-\mathrm{MG}$ & & & & & \\
\hline $\mathrm{A}$ & $0-30$ & 5.0 & 4.0 & 0.11 & 0.53 & 0.24 & 0.18 & 3.35 & 5.25 & 9.66 & 76 \\
\hline A2 & $30-60$ & 4.5 & 4.3 & 0.06 & 0.56 & 0.05 & 0.02 & 2.28 & 4.02 & 6.99 & 77 \\
\hline A3 & $60-75$ & 4.7 & 4.4 & 0.06 & 0.52 & 0.04 & 0.02 & 1.86 & 3.52 & 6.01 & 75 \\
\hline A4 & $75-100$ & 4.8 & 4.4 & 0.05 & 0.58 & 0.03 & 0.01 & 1.61 & 3.17 & 5.45 & 71 \\
\hline $\mathrm{AB}$ & $100-130$ & 5.0 & 4.5 & 0.04 & 0.56 & 0.03 & 0.00 & 1.29 & 3.11 & 5.04 & 67 \\
\hline $\mathrm{BA}$ & $130-160$ & 5.1 & 4.5 & 0.04 & 0.56 & 0.03 & 0.00 & 1.06 & 2.60 & 4.29 & 63 \\
\hline $\mathrm{Bw}$ & $160-210$ & 5.0 & 4.6 & 0.03 & 0.54 & 0.04 & 0.00 & 0.56 & 2.11 & 3.28 & 48 \\
\hline
\end{tabular}

(1) CEC: cation exchange capacity. ${ }^{(2)} \mathrm{m} \%$ : Al saturation. 
Table 5. Contents of carbon (TC, OC, C-res and C-labile) and TN, and C/N ratio in the UF studied. Rows in bold refer to charcoal fragment lines

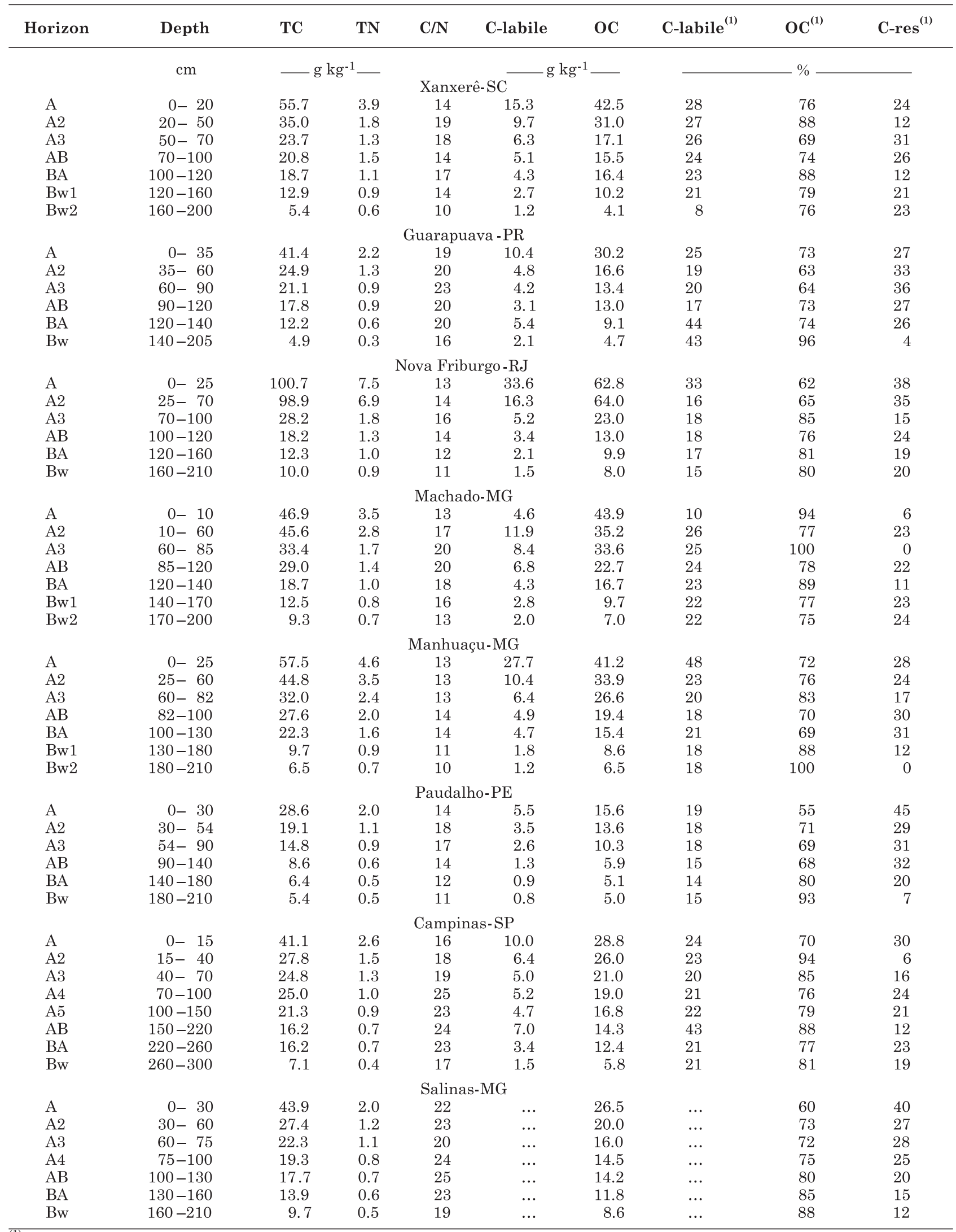

(1) Percentage in relation to total $\mathrm{C}$. 
Paudalho-PE under Deciduous Seasonal Submountainous Forest. The climate of this pedon is tropical with dry summer seasons (As'), which is favorable for a rapid decomposition of soil OM.

A C/N ratio between 12 and 16 of the epipedon reflects the dominance of humidified OM (Stevenson, 1994). The $\mathrm{C} / \mathrm{N}$ ratio calculated for the humic epipedon of the soils studied was higher than these values (13-25) and increased with depth. These values, however, decreased toward the Bw horizon, which can be explained by the major input of plant material near the surface. Furthermore, in the pedons of Campinas$\mathrm{SP}$ and Salinas-MG, located in regions with less rainfall and with clear lines of charcoal fragments in the soil matrix, the values of the $\mathrm{C} / \mathrm{N}$ ratio were highest.

The OC oxidation with dichromate $\left(\mathrm{Cr}_{2} \mathrm{O}_{7}{ }^{2-}\right)$ accounted for an average $75 \%$ of the TC of humic epipedons of Ferralsols. Therefore, $3 / 4$ of the TC reserves in the epipedon is not very recalcitrant and other mechanisms of $\mathrm{C}$ stabilization may help to maintain the TC content in depth high in the pedons studied. Carbon compounds resistant to dichromate oxidation (C-res) made up the remaining $25 \%$ of the $\mathrm{TC}$ in the epipedon. This fraction (C-res) supposedly includes: (i) highly recalcitrant $\mathrm{C}$ forms, including pyrogenic C (black carbon), and/or (ii) organic compounds strongly associated with the clay fraction (kaolinite and $\mathrm{Fe}$ and $\mathrm{Al}$ oxides).

There are to date no standard methods for an accurate determination of the black carbon (BC) content in terrestrial environments (Masiello et al., 2007). Moreover, results of measurements of the BC concentration in the soil by different methods vary up to 500 times (Schmidt et al., 2001). The fact that soil BC does not stand for a single variable, but rather a continuum (different levels of carbonized biomass), makes quantification difficult.

In most horizons, the C-labile fraction represented about $20 \%$ of TC. The surface horizons of LAd of Nova Friburgo-RJ and Manhuaçu-MG, located in a mild mountainous climate, are constantly supplied with fresh material by the Rain Forest (Dense Mountainous Ombrophylous Forest and Semidecidual Mountainous Seasonal Forest) and have the largest labile $\mathrm{C}$ reserves.

\section{Mineralogy and selective extraction}

The $\mathrm{Fe}_{0}$ and $\mathrm{Al}_{\mathrm{o}}$ contents ranged from 0.8 to $5.9 \mathrm{~g} \mathrm{~kg}^{-1}$; and from 1.3 to $14.0 \mathrm{~g} \mathrm{~kg}^{-1}$, respectively, in the humic epipedon. The highest $\mathrm{Fe}_{\mathrm{d}}$ contents were found in UF samples from Xanxerê-SC and Guarapuava-PR, evidencing the nature of the parent material, rich in ferromagnesian minerals. The values of the ratio $\mathrm{Fe}_{0} / \mathrm{Fe}_{\mathrm{d}}$ were low $(<8 \%)$ due to the strong predominance of these crystalline forms in these Ferralsols (Table 6). These values decreased with depth indicating a higher degree of crystallinity of $\mathrm{Fe}$ oxides in the subsurface horizons. This is in accordance with the distribution and influence of OC in these pedons, which is an important inhibitor of oxide crystallization (Cornell \& Schwertmann, 1996). The lowest $\mathrm{Fe}_{\mathrm{o}} / \mathrm{Fe}_{\mathrm{d}}$ ratio was recorded in the LAd of Paudalho-PE, which was derived from clayey-sandy sediments and also had the lowest OC content of the soils studied.

Most pedons were classified as kaolinite $(\mathrm{Ki}>0.75$ and $\mathrm{Kr}>0.75)$ or kaolinitic-oxidic $(\mathrm{Ki}>0.75$ and $\mathrm{Kr} \leq 0.75$ ), according to Embrapa (2006), while the LAd of Nova Friburgo-RJ and LBw of Guarapuava$\mathrm{PR}$ were classified as gibbsitic-oxidic ( $\mathrm{Ki} \leq 0.75$ and $\mathrm{Kr} \leq$ 0.75) (Table 6).

The kaolinite (Kt) was the main clay mineral in all pedons identified by XRD, followed by gibbsite (Gb), absent only in pedons of Salinas-MG and Paudalho$\mathrm{PE}$, and by hydroxy-interlayered vermiculite (HIV) that was identified in the diffractograms of the LVdf of Xanxerê-SC and LBw of Guarapuava-PR. The identification of HIV is in agreement with other studies of Ferralsols in Southern Brazil (Ker, 1988; Ghidin et al., 2006a).

The XRD patterns obtained were similar, and the $\mathrm{Kt}$ peaks were always more intense than those of $\mathrm{Gb}$, except for the LAd in Nova Friburgo-RJ, where the Gb peaks were most intense, in agreement with the low Ki values (0.4 and 0.6 for horizons A3 and $\mathrm{Bw}$, respectively) in this pedon.

The gibbsite formation was favored by intense leaching and alitization, destroying the 1:1 type minerals, especially kaolinite. Direct formation from primary minerals (feldspars and plagioclase) can also occur under intense leaching (Schaefer et al., 2002). However, it must be taken into account that gibbsite crystallization can be completely inhibited by low soil pH and high OM contents (Hsu, 1989). Therefore, for the humic LAd of Nova Friburgo-RJ, gibbsite nucleation is rather unlikely near the surface in the present environmental conditions, where an OM-rich horizon was formed. The gibbsite found in the humic epipedon of this pedon must have therefore been formed in the past in a possibly warmer and more seasonal scenario, prior to OM accumulation. This finding corroborates the model proposed by Simas et al. (2005) and Modenesi Gauttieri \& Toledo (1996) for the development of Ferralsols in the Serra da Mantiqueira (MG) and Serra da Itatiaia (RJ), respectively.

\section{Correlation analysis}

With few exceptions, TC contents were independent from most variables tested (Table 7). This variable correlated positively and significantly with $\mathrm{OC}(\mathrm{r}=$ $0.97, \mathrm{P}<0.001)$, with the $\mathrm{C}$ non-oxidized with dichromate (C-res) $(r=0.90, \mathrm{P}<0.001)$ and with the C-labile fraction $(r=0.88, \mathrm{P}<0.001)$. Correlations between TC and OC were also found in other tropical areas, as in Ferralsols of the Colombian Amazon (Buurman \& Mosquera, 2008). 
Table 6. Contents of $\mathrm{SiO}_{2}, \mathrm{Al}_{2} \mathrm{O}_{3}, \mathrm{Fe}_{2} \mathrm{O}_{3}$ and $\mathrm{TiO}_{2}$, molecular ratios, mineralogy of the clay fraction and $\mathrm{Fe}$ and $\mathrm{Al}$ contents extracted with DCB or AAO from the studied soils

\begin{tabular}{|c|c|c|c|c|c|c|c|c|c|c|c|c|}
\hline Horizon & $\mathrm{SiO}_{2}$ & $\mathrm{Al}_{2} \mathrm{O}_{3}$ & $\mathrm{Fe}_{2} \mathrm{O}_{3}$ & $\mathrm{TiO}_{2}$ & $\mathbf{K i}$ & $\mathbf{K r}$ & $\begin{array}{c}\text { Mineralogy of } \\
\text { the clay } \\
\text { fraction } \\
(1)\end{array}$ & $\mathrm{Fe}_{\mathrm{o}}$ & $\mathrm{Al}_{\mathrm{o}}$ & $\mathrm{Fe}_{\mathbf{d}}$ & $\mathrm{Al}_{\mathrm{d}}$ & $\mathrm{Fe}_{\mathrm{o}} / \mathrm{Fe}_{\mathrm{d}}$ \\
\hline & \multicolumn{6}{|c|}{ - $\mathrm{g} \mathrm{kg}^{-1}$} & & \multicolumn{4}{|c|}{$\mathrm{g} \mathrm{kg}^{-1}$} & $\%$ \\
\hline A & $\ldots$ & $\ldots$ & 0.0 & $\ldots$ & $\ldots$ & $\ldots$ & $\begin{array}{c}\text { Xanxerê-SC } \\
\ldots\end{array}$ & 5.9 & 5.7 & 70.5 & 16.1 & 8.4 \\
\hline A2 & $\ldots$ & $\ldots$ & $\ldots$ & $\ldots$ & $\ldots$ & $\ldots$ & $\mathrm{Kt}>\mathrm{Gb}>\mathrm{HIV}$ & 5.5 & 6.1 & 71.1 & 16.3 & 7.7 \\
\hline A3 & $\ldots$ & $\ldots$ & $\ldots$ & $\ldots$ & $\ldots$ & $\ldots$ & $\ldots$ & 4.5 & 5.2 & 72.2 & 16.0 & 6.2 \\
\hline $\mathrm{AB}$ & 199 & 229.2 & 174.1 & 25.7 & 1.5 & 1.0 & & $\ldots$ & $\ldots$ & $\ldots$ & $\ldots$ & $\ldots$ \\
\hline BA & & $\ldots$ & $\ldots$ & $\ldots$ & $\ldots$ & $\ldots$ & $\mathrm{Kt}>\mathrm{Gb}>\mathrm{HIV}$ & $\ldots$ & $\ldots$ & $\ldots$ & $\ldots$ & $\ldots$ \\
\hline Bw2 & 185 & 243.9 & 186.3 & 26.1 & 1.3 & 0.9 & $\ldots$ & $\ldots$ & $\ldots$ & $\ldots$ & $\ldots$ & $\ldots$ \\
\hline & & & & & & & Guarapuava-PR & & & & & \\
\hline A & $\ldots$ & $\ldots$ & $\ldots$ & $\ldots$ & $\ldots$ & $\ldots$ & $\ldots$ & 3.6 & 6.5 & 63.9 & 27.9 & 5.6 \\
\hline A2 & $\ldots$ & $\ldots$ & $\ldots$ & $\ldots$ & $\ldots$ & $\ldots$ & $\ldots$ & 2.8 & 5.8 & 66.8 & 23.1 & 4.2 \\
\hline A3 & 107 & 291. 2 & 150. 2 & 21.2 & 0.6 & 0.5 & $\ldots$ & 2.7 & 5.6 & 67.9 & 22.3 & 4.0 \\
\hline $\mathrm{AB}$ & & $\ldots$ & $\ldots$ & $\ldots$ & $\ldots$ & $\ldots$ & $\mathrm{Kt}>\mathrm{Gb}>>\mathrm{Gt}^{\prime}>\mathrm{Hm}^{(4)}$ & $\ldots$ & $\ldots$ & $\ldots$ & $\ldots$ & $\ldots$ \\
\hline $\mathrm{Bw}$ & 131 & 308.1 & $\dddot{152.1}$ & 20.2 & 0.7 & 0.6 & $\mathrm{Kt}>\mathrm{Gb}>>\mathrm{Hm}>\mathrm{Gt}^{(4)}$ & $\ldots$ & $\ldots$ & $\ldots$ & $\ldots$ & $\ldots$ \\
\hline A & $\ldots$ & $\ldots$ & $\ldots$ & $\ldots$ & $\ldots$ & $\ldots$ & $\begin{array}{c}\text { Nova Friburgo-RJ } \\
\ldots\end{array}$ & 2.5 & 12.6 & 44.8 & 25.5 & 5.6 \\
\hline A2 & $\ldots$ & $\ldots$ & $\ldots$ & $\ldots$ & $\ldots$ & $\ldots$ & $\ldots$ & 3.0 & 14.0 & 45.1 & 31.3 & 6.6 \\
\hline A3 & 61 & 231.3 & 76.1 & 7.0 & 0.4 & 0.4 & $\mathrm{Kt}>\mathrm{Gb}$ & 1.3 & 5.4 & 48.2 & 18.9 & 2.7 \\
\hline $\mathrm{Bw}$ & 87 & 245.0 & 87.6 & 7.1 & 0.6 & 0.5 & $\mathrm{Kt}>\mathrm{Gb}$ & $\ldots$ & $\ldots$ & $\ldots$ & $\ldots$ & $\ldots$ \\
\hline A2 & & & & & & & Machado-MG & 34 & 5.9 & 519 & 150 & 66 \\
\hline A3 & $\begin{array}{l}\cdots \\
\cdots\end{array}$ & $\begin{array}{l}\cdots \\
\cdots\end{array}$ & $\begin{array}{l}\cdots \\
\cdots\end{array}$ & $\begin{array}{l}\cdots \\
\ldots\end{array}$ & $\begin{array}{l}\cdots \\
\cdots\end{array}$ & $\begin{array}{l}\cdots \\
\ldots\end{array}$ & $\begin{array}{c}\mathrm{K} t>\mathrm{Gb} \\
\ldots\end{array}$ & $\begin{array}{l}3.4 \\
3.9\end{array}$ & $\begin{array}{l}0.9 \\
5.9\end{array}$ & $\begin{array}{l}01.9 \\
46.7\end{array}$ & $\begin{array}{l}10.0 \\
13.1\end{array}$ & $\begin{array}{l}.0 .0 \\
8.3\end{array}$ \\
\hline $\mathrm{AB}$ & 174 & 247.1 & 86.7 & 7.7 & 1.2 & 1.0 & $\begin{array}{l}\ldots \\
\ldots\end{array}$ & 2.8 & 5.2 & 51.6 & 13.3 & 5.4 \\
\hline $\mathrm{BA}$ & $\ldots$ & $\ldots$ & $\ldots$ & $\ldots$ & $\ldots$ & $\ldots$ & $\mathrm{Kt}>\mathrm{Gb}$ & $\ldots$ & $\ldots$ & $\ldots$ & $\ldots$ & $\ldots$ \\
\hline Bw2 & 185 & 261.8 & 87.8 & 7.9 & 1.2 & 1.0 & $\ldots$ & $\ldots$ & $\ldots$ & $\ldots$ & $\ldots$ & $\ldots$ \\
\hline & & & & & & & Manhuaçu-MG & & & & & \\
\hline A & $\ldots$ & $\ldots$ & $\ldots$ & $\ldots$ & $\ldots$ & $\ldots$ & $\ldots$ & 2.7 & 3.2 & 50.5 & 19. 2 & 5.3 \\
\hline A2 & $\ldots$ & $\ldots$ & $\ldots$ & $\ldots$ & $\ldots$ & $\ldots$ & $\ldots$ & 3.0 & 3.8 & 52.9 & 17.3 & 5.6 \\
\hline A3 & $\ldots$ & $\ldots$ & $\ldots$ & $\ldots$ & $\ldots$ & $\ldots$ & $\mathrm{Kt}>\mathrm{Gb}$ & 2.8 & 4.5 & 55.0 & 18.0 & 5.0 \\
\hline $\mathrm{AB}$ & 121 & 239.7 & 91.5 & 11.5 & 0.9 & 0.7 & & $\ldots$ & $\ldots$ & $\ldots$ & $\ldots$ & $\ldots$ \\
\hline $\mathrm{Bw} 1$ & $\ldots$ & $\ldots$ & $\ldots$ & $\ldots$ & $\ldots$ & $\ldots$ & $\mathrm{Kt}>\mathrm{Gb}$ & $\ldots$ & $\ldots$ & $\ldots$ & $\ldots$ & $\ldots$ \\
\hline Bw2 & 131 & 244.4 & 102.1 & 11.9 & 0.9 & 0.7 & $\ldots$ & $\ldots$ & $\ldots$ & $\ldots$ & $\cdots$ & $\ldots$ \\
\hline & & & & & & & Paudalho-PE & & & & & \\
\hline A & $\ldots$ & $\ldots$ & $\ldots$ & $\ldots$ & $\ldots$ & $\ldots$ & $\ldots$ & 1.0 & 1.3 & 35.7 & 3.3 & 2.8 \\
\hline A2 & $\ldots$ & $\ldots$ & $\ldots$ & $\ldots$ & $\ldots$ & $\ldots$ & $\ldots$ & 1.0 & 1.4 & 39.1 & 4.0 & 2.6 \\
\hline A3 & 148 & 148.8 & 32.2 & 5.6 & 1.7 & 1.5 & $\mathrm{Kt}$ & 0.8 & 1.3 & 37.4 & 4.2 & 2.1 \\
\hline $\mathrm{Bw}$ & 188 & 185.0 & 41.1 & 6.3 & 1.7 & 1.5 & $\mathrm{Kt}$ & $\ldots$ & $\ldots$ & $\ldots$ & $\ldots$ & $\ldots$ \\
\hline & & & & & & & Campinas-SP & & & & & \\
\hline A2 & $\ldots$ & $\ldots$ & $\ldots$ & $\ldots$ & $\ldots$ & $\ldots$ & $\mathrm{K} \mathrm{t}>\mathrm{Gb}$ & 1.9 & 4.0 & 44.1 & 8.7 & 4.3 \\
\hline A4 & $\ldots$ & $\ldots$ & $\ldots$ & $\ldots$ & $\ldots$ & $\ldots$ & $\ldots$ & 1.6 & 3.3 & 44.8 & 9.0 & 3.6 \\
\hline A5 & 102 & 193.5 & 53.1 & 5.7 & 0.9 & 0.8 & $\ldots$ & 1.4 & 4.0 & 44.0 & 12.3 & 3.2 \\
\hline $\mathrm{Bw}$ & 112 & 211.3 & 57.4 & 5.8 & 0.9 & 0.8 & $\mathrm{Kt}>\mathrm{Gb}$ & $\ldots$ & $\ldots$ & $\ldots$ & $\ldots$ & $\ldots$ \\
\hline A & $\ldots$ & $\ldots$ & $\ldots$ & $\ldots$ & $\ldots$ & $\ldots$ & $\begin{array}{c}\text { Salinas-MG } \\
\ldots\end{array}$ & 2.0 & 4.2 & 44.3 & 8.1 & 4.5 \\
\hline $\mathrm{A} 2$ & $\cdots$ & $\cdots$ & $\cdots$ & 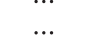 & $\cdots$ & $\begin{array}{l}\cdots \\
\ldots\end{array}$ & $\ldots$ & 2.0 & 4.4 & 45.5 & 8.4 & 4.4 \\
\hline A3 & 195 & 243.9 & 59.9 & 11.0 & 1.4 & 1.2 & $\mathrm{Kt}$ & 2.0 & 4.5 & 44.5 & 7.6 & 4.5 \\
\hline A4 & $\ldots$ & $\ldots$ & $\ldots$ & $\ldots$ & $\ldots$ & $\ldots$ & $\ldots$ & 1.7 & 4.3 & 44.4 & 7.6 & 3.8 \\
\hline $\mathrm{Bw}$ & 219 & 241.8 & 69.9 & 11.2 & 1.5 & 1.3 & $\mathrm{Kt}$ & $\ldots$ & $\ldots$ & $\ldots$ & $\ldots$ & $\ldots$ \\
\hline
\end{tabular}

(1) Exclusive for Fe oxides, except for the pedon of Guarapuava-PR. Kaolinite: Kt; Gibbsite: Gb; HIV= Hydroxy-interlayered vermiculite; Goethite: Gt; Hematite: Hm. ${ }^{(2)}$ AAO: Ammoniac Acid Oxalate. ${ }^{(3)}$ DCB: dithionite-citrate-bicarbonate. ${ }^{(4)}$ Obtained from Ghidin et al. (2006a).

These correlations suggest that, in most horizons, the irregular charcoal contents in depth did not interfere with the TC contents, and that part of this fraction must be strongly associated with the soil mineral fraction. If organic compounds derived from charcoal played a role, it would be as a largely humidified fraction and immobilized of TC. Since the macroscopic charcoal fragments were removed during sample preparation, when retained in the sieve $(1 \mathrm{~mm}$ mesh), they did not influence the TC content of the ADFE. Considering that the non-oxidized fraction with dichromate (C-res) is obtained by subtraction, the result is supposedly rather misleading, which may be the cause for a lower correlation with TC. 
Table 7. Linear correlation coefficients (r) between $\mathrm{C}$ forms in the soil and between these and other variables of $A$ and $B$ horizons

\begin{tabular}{|c|c|c|c|c|}
\hline Parameters & TC & $\mathrm{OC}$ & C-res C & C-labile \\
\hline $\mathrm{TC}(\mathrm{n}=47)$ & 1 & & & \\
\hline $\mathrm{OC}(\mathrm{n}=47)$ & $0.97^{* * *}$ & 1 & & \\
\hline C-res $(\mathrm{n}=47)$ & $0.90^{* * *}$ & $0.78^{* * *}$ & 1 & \\
\hline C-labile $(\mathrm{n}=47)$ & $0.88^{* * *}$ & $0.85^{* * *}$ & $0.83^{* * *}$ & 1 \\
\hline Clay $(\mathrm{n}=47)$ & $-0.49^{* * *}$ & $-0.47^{* * *}$ & $-0.46^{* * *}$ & ${ }^{*}-0.36^{*}$ \\
\hline Sand $(n=47)$ & 0.20 & 0.20 & 0.17 & 0.10 \\
\hline $\operatorname{Ds}(n=46)$ & $-0.45^{* *}$ & $-0.47^{* *}$ & $-0.34^{*}$ & $-0.37^{*}$ \\
\hline $\mathrm{pH}(\mathrm{n}=47)$ & -0.21 & -0.24 & -0.12 & -0.23 \\
\hline Effective CEC (n=47) & 0.03 & -0.04 & 0.16 & 0.06 \\
\hline Exchangeable $\mathrm{Al}^{3+}(\mathrm{n}=47)$ & $0.37^{*}$ & $0.44^{* *}$ & 0.17 & $0.36^{*}$ \\
\hline $\mathrm{Al}^{3+}$ saturation $(\mathrm{n}=47)$ & 0.27 & $0.35^{*}$ & 0.08 & 0.19 \\
\hline $\mathrm{Fe}_{o}(\mathrm{n}=21)^{(1)}$ & 0.36 & 0.40 & 0.12 & 0.29 \\
\hline $\mathrm{Al}_{\mathrm{o}}(\mathrm{n}=21)^{(1)}$ & $0.83^{* * *}$ & $0.81^{* * *}$ & $0.76^{\star \star * *}$ & ${ }^{*} \quad 0.58^{*}$ \\
\hline $\mathrm{Fe}_{\mathrm{d}}(\mathrm{n}=21)^{(1)}$ & -0.04 & $0.00^{(2)}$ & -0.11 & -0.01 \\
\hline $\mathrm{Al}_{\mathrm{d}}(\mathrm{n}=21)^{(1)}$ & $0.63^{* *}$ & $0.63^{* *}$ & $0.58^{* *}$ & $0.49^{* *}$ \\
\hline
\end{tabular}

(1) Only for A horizons. *, ${ }^{* *},{ }^{* * *}$ Significant at $\mathrm{P}<0.05, \mathrm{P}<0.01$, and $\mathrm{P}<0.001$, respectively.

Among the inorganic parameters, poorlycrystalline $\mathrm{Al}$ extracted with $\mathrm{AAO}\left(\mathrm{Al}_{\mathrm{o}}\right)$ is most significantly correlated with TC. It alone explains $69 \%\left(\mathrm{r}^{2}=0.69\right)$ of the TC variation in epipedons, and $66 \%$ and $58 \%$ of the OC and C-res, respectively. The lower value for C-res again may be explained by its large error. In oxide-rich soils, $\mathrm{Al}_{\mathrm{d}}$ contains part of the amorphous fraction extracted with $\mathrm{AAO}$ solution and $\mathrm{Al}$ substituted by Fe minerals, such as goethite. Once $\mathrm{Al}_{\mathrm{d}}$ contents were not characterized as a homogeneous fraction, the correlations were not as high as those obtained for $\mathrm{Al}_{0}$. Clay content explained only $24 \%$ of the variation in TC content and $20 \%$ of bulk density (BD). Other parameters were not suited as indicators of the different carbon fractions.

The results suggested that for the humic epipedon of Brazilian Ferralsols, organic compounds were predominantly associated with poorly-crystalline minerals represented mainly by $\mathrm{Al}_{0}$, once $\mathrm{Fe}_{0}$ occurred in smaller amounts (Table 6).

\section{CONCLUSIONS}

1. The physical and chemical properties of the pedons, e.g., clayey to very clayey texture, strongly acidic $\mathrm{pH}$, dystrophy, and high $\mathrm{Al}$ saturation tend to delay SOM decomposition.

2. Organic compounds that are highly recalcitrant or strongly associated with clay minerals (C-res) account for 6-25\% of TC of the humic epipedon, while the oxidizable fraction $(\mathrm{OC})$ represents the major part of the TC reserves in these Ferralsols. This indicates that the OM of UFs is not essentially composed of pyrogenic $\mathrm{C}$.
3. Regardless of the location of the vegetation, the $\mathrm{C} / \mathrm{N}$ ratio of epipedons increases with depth, indicating a lower degree of OM decomposition in the subsurface.

4. Interactions between different forms of carbon and poorly-crystalline aluminum $\left(\mathrm{Al}_{0}\right)$ represent a mechanism of carbon protection in the humic epipedon.

\section{ACKNOWLEDGEMENTS}

The authors thank the Foundation for Research Support of São Paulo - FAPESP (Research Project 06/58068-6) and the National Council for Scientific and Technological Development $(\mathrm{CNPq})$ for granting scholarships in Brazil and abroad.

\section{LITERATURE CITED}

ANDRADE, F.V.; SCHAEFER, C.E.G.R.; CORREA, M.L.T. \& MENDONÇA, E.S. Carbon stocks in Brazilian Latosols (Oxisols) from different morphoclimatic regions and management systems. Comm. Soil Sci. Plant Anal., 35:2125-2136, 2004.

BIRD, M.I.; MOYO, C.; VEENENDAAL, E.M.; LIOYD, J. \& FROST, P. Stability of elemental carbon in a savanna soil. Glob. Biogeochem. Cycles, 13:923-932, 1999.

BLAIR, G.J.; LEFROY, R.D.B. \& LISLE, L. Soil carbon fractions based on their degree of oxidation, and the development of a carbon management index for agricultural systems. Austr. J. Soil Res., 46:1459-1466, 1995 .

BROWN, G. \& BRINDLEY, G.W. X ray Diffraction Procedures for clay mineral Identification. In: BRINDLEY, G.W. \& BROWN, G., eds. Mineralogical society. London, 1980. p.305-360.

BUOL, S.W. \& ESWARAN, H. Latosols. Adv. Agron., 68:151$195,2000$.

BUURMAN, P. \& MOSQUERA, O. Analysis of soil variability and data consistency. In: 'tMANNETJE, L.; AMEZQUITA, M.C.; BUURMAN, P. \& IBRAHIM, M. eds. Carbon sequestration in tropical grassland systems. Wageningen, Academic Publishers, 2008. p.69-90.

CALEGARI, M.R. Ocorrência e significado paleoambiental do horizonte A húmico em Latossolos. Piracicaba, Escola Superior de Agricultura Luiz de Queiroz, 2008. 259p. (Tese de Doutorado)

COFFIN, D.E. A method for determination of free iron in soils and clays. Can. J. Soil Sci., 43:7-17, 1963.

CORNELL, P.M. \& SCHWERTMANN, U. The iron oxides. Structure, properties, reactions, occurrence and uses. Weinheim, VCH 1996. 573p.

CZIMCZIK, C.I. \& MASIELLO, C.A. Controls on black carbon storage in soils. Glob. Biogeochem. Cycles, 21:1-8, 2007. 
DICK, D.P.; GONCALVES, C.N.; DALMOLIN, R.S.D.; KNICKER, H.; KLAMT, E.; KÖGEL-KNABNER, I.; SIMÕES, M.L. \& MARTIN NETO, L. Characteristics soil organic matter of different Brazilian Latosols under native vegetation as a function of soil depth. Geoderma, 124:319-333, 2005.

DONAGEMMA, G.K.; RUIZ, H.A.; FONTES, M.P.F.; KER, J.C. \& SCHAEFER, C.H.G.R. Dispersão de Latossolos em resposta à utilização de pré-tratamentos na análise textural. R. Bras. Ci. Solo, 27:765-772, 2003.

DÜMIG, A.; SCHAD, P.; RUMPEL, C.; DIGNAC, M.F. \& KNABNER-KÖGEL, I. Araucaria forest expansion on grassland in the southern Brazilian highlands as revealed by ${ }^{14} \mathrm{C}$ and ${ }^{13} \mathrm{C}$ studies. Geoderma, $145: 143$ 157,2008

EMPRESA BRASILEIRA DE PESQUISA AGROPECUÁRIA - EMBRAPA. Centro Nacional de Pesquisa de Solos. Manual de métodos de análise de solo. 2.ed. Rio de Janeiro, 1997. 212p.

EMPRESA BRASILEIRA DE PESQUISA AGROPECUÁRIA - EMBRAPA. Centro Nacional de Pesquisa de Solos. Sistema brasileiro de classificação de solos. 2.ed. Rio de Janeiro, 2006. 306p.

FAO-UNESCO. Soil Map of the World (1:5.000.000) v.1-10 Paris. UNESCO, 1971-1981.

GHIDIN, A.A.; MELO, V.F.; LIMA, V.C. \& LIMA, J.M.J.C. Toposseqüências de Latossolos originados de rochas basálticas no Paraná. I. Mineralogia da fração argila. R. Bras. Ci. Solo, 30.293-306, 2006a.

GHIDIN, A.A.; MELO, V.F.; LIMA, V.C. \& LIMA, J.M.J.C. Toposseqüências de Latossolos originados de rochas basálticas no Paraná. II. Relação entre mineralogia da fração argila e propriedades físicas dos solos. R. Bras. Ci. Solo, 30:307-319, 2006b.

GOUVEIA, S.E.M.; PESSENDA, L.C.R.; BOUFET, R.; ARAVENA, R. \& SCHEEL-YBERT, R. Isótopos de carbono dos carvões e da matéria orgânica do solo em estudos de mudança de vegetação e clima no Quaternário e da taxa de formação de solos no Estado de São Paulo. An. Acad. Bras. Ci., 71:4-II, 1999.

HSU, P.H. Aluminium hydroxides and oxyhydroxides. In: DIXON, J.B. \& WEED, S.B., eds. Minerals in soil environments. Madison, SSSA, 1989. p.1051-1088.

INSTITUTO BRASILEIRO DE GEOGRAFIA E ESTATÍSTICA - IBGE. Manual técnico da vegetação brasileira. Rio de Janeiro, 1992. (Manuais Técnicos em Geociências, 1)

INSTITUTO BRASILEIRO DE GEOGRAFIA E ESTATÍSTICA - IBGE. Mapa de vegetação do Brasil. Rio de Janeiro, 2004a.

INSTITUTO BRASILEIRO DE GEOGRAFIA E ESTATÍSTICA - IBGE. Mapa de biomas do Brasil. Rio de Janeiro, 2004b.

JACKSON, M.L. Soil chemical analysis: Advanced course. Madison, University of Wisconsin, 1956. 894p.
KÄMPF, N. \& SCHWERTMANN, U. Goethite and hematite in a climosequence in Southern Brazil and their application in classification of kaolinitic soils. Geoderma, 29:27-39, 1983.

KER, J.C. Caracterização química, física, mineralógica e micromorfológica de solos brunos subtropicais. Viçosa, MG, Universidade Federal de Viçosa, 1988. 148p. (Tese de Mestrado)

KER, J.C. Latossolos do Brasil: Uma revisão. Geonomos, 5:17-40, 1997

KNICKER, H.; HILSCHER, A.; GONZÁLEZ-VILA, F.J. \& ALMENDROS, G. A new conceptual model for the structural properties of char produced during vegetation fires. Org. Geochem., 39:935-939, 2008.

KNICKER, H.; MÜLLER, P. \& HILSCHER, A. How useful is chemical oxidation with dichromate for the determination of "Black Carbon" in fire-affected soils? Geoderma, 142:178-196, 2007.

LEPSCH, I.F. \& BUOL, S.W. Oxisol-landscape relationship in Brazil. In: INTERNATIONAL SOIL CLASSIFICATION WORKSHOP, 13., Campinas, 1986. Anais...Campinas, SNLCS/EMBRAPA/University of Puerto Rico, 1986. p.174-189.

MASIELlO, C.A.; MITRA, S.; GUSTAFSSON, O.; LOUCHOUARN, P.; HOUEL, S.; ELMQUIST, M.; CORNELISSEN, G.; SONG J.; DUNN, J.C.; SMITH, D.M.; HARTKOPF-FROEDER, C.; BOEHMER, A.; LUEER, B.; HUEBERT, B.J.; PENG, P.A.; HOCKADAY, W.C.; SKJEMSTAD, J.O.; AMELUNG, W.; HAMMES, K.; HATCHER, P.G.; SCHMIDT, M.W.I.; SMERNIK, R.J.; CURRIE, L.A.; BALL, W.P. \& NGUYEN, T.H. Comparison of quantification methods to measure firederived (black/elemental) carbon in soils and sediments using reference materials from soil, water, sediment and the atmosphere, Glob. Biogeochem. Cycles, 2:1-18, 2007.

MIKLÓS, A.A.W. Byodinamique d'une couverture pedologique dans la région de Botucatu, Brésil. Paris, Université Paris, 1992. 438p. (Tese de Doutorado)

MODENESI GAUTTIERI, M.C. \& TOLEDO, M.C.M. Weathering and the formation of hillslope deposits in the tropical highlands of Itatiaia-southeastern Brazil. Catena, 27:81-103, 1996.

NOVOTNY, E.H.; DEAZEVEDO, E.R.; BONAGAMBA, T.J.; CUNHA, T.J.F.; MADARI, B.E.; BENITES, V.M. \& HAYES, M.H.B. Studies of the compositions of humic acids from Amazonian dark earth soils. Environ. Sci. Technol., 41:400-405, 2007.

PESSENDA, L.C.R.; ARAVENA, R.; MELFI, A.J. \& BOUFET, $R$. The use of carbon isotopes (C-13, C-14) in soil to evaluate vegetation changes during the Holocene in central Brazil. Radiocarbon, 38:191-201, 1996.

PESSENDA, L.C.R.; GOUVEIA, S.E.M.; ARAVENA, R.; BOUFET, R. \& VALENCIA, E.P.E. Holocene Fire and vegetation changes in southeastern Brazil as deduced from fossil charcoal and soil carbon isotopes. Quatern. Intern., 114:35-43, 2004. 
QUEIROZ NETO, J.P. \& CASTRO, S.S. Formações superficiais e Latossolos Vermelho-Amarelo húmico na área de Bragança Paulista, Estado de São Paulo, Brasil. In: CONGRESSO BRASILEIRO DE GEOLOGIA 18. Porto Alegre, 1974. Anais. Porto Alegre, Sociedade Brasileira de Geologia, 1974. p.65-83.

RESENDE, M. \& SANTANA, D.P. Uso das relações Ki e Kr na estimativa da mineralogia para classificação dos Latossolos. In: REUNIÃO DE CLASSIFICAÇÃO, CORRELAÇÃO DE COLOS E INTERPRETAÇÃO DE APTIDÃO AGRÍCOLA. 3., Rio de Janeiro, 1988. Anais. Rio de Janeiro, EMBRAPA-SNLCS/SECS, 1988. p.225229 .

ROSCOE, R.; BUURMAN, P.; VELTHORST, E.J. \& VASCONCELOS, C.A.A. Soil organic matter dynamics in density and particle-size fractions as revealed by the ${ }^{13} \mathrm{C} /{ }^{12} \mathrm{C}$ isotopic ratio in a Cerrrado's Oxisol. Geoderma, 104:185-202, 2001.

SANTOS, R.D.; LEMOS, R.C.; SANTOS, H.G.; KER, J.C. \& ANJOS, L.H. Manual de descrição e coleta de solo no campo. 5.ed. Viçosa, MG, Sociedade Brasileira de Ciência do Solo, 2005. 100p.

SCHAEFER C.E.R. Brazilian latosols and their B horizon microstructure as long-term biotic constructs. Austr. J. Soil Res., 39:909-926, 2001.

SCHAEFER C.E.R.; KER, J.C.; GILKES, R.J.; CAMPOS, J.C.; COSTA, L.M. \& SAADI, A. Pedogenesis on the uplands of the Diamantina Plateau, Minas Gerais, Brazil: A chemical and micropedological study. Geoderma, 107:243-269, 2002.

SCHMIDT, M.W.I.; SKJEMSTAD, J.O.; CZIMCZIK, C.I.; GLASER, B.; PRENTICE, K.M.; GELINAS, Y. \& KUHLBUSCH, T.A.J. Comparative analysis of black carbon in soils. Glob. Biogeochem. Cycles, 15:163-167, 2001.

SCHMIDT, M.W.I.; SKJEMSTAD, J.O.; GEHRT, E. \& KOGEL-KNABNER, I. Charred organic carbon in German chernozemic soils. Europ. J. Soil Sci., 50:351365, 1999.
SCHWERTMANN, U. Transformation of hematite to goethite in soils. Nature, 232:625, 1971.

SCHWERTMANN, U. \& TAYLOR, R.M. Iron oxides. In: DIXON, J.B. \& WEED, S.B., eds. Minerals in soil environments. 2.ed. Madison, Soil Science Society of America, 1989. p.380-427.

SHINDO, H.; HONNA, T.; YAMAMOTO, S. \& HONNA, H. Contribution of charred plant fragments to soil organic carbon in Japanese volcanic ash soils containing black humic acids. Org. Geochem., 35:235-241, 2004.

SILVA, A.C. \& VIDAL-TORRADO, P. Gênese dos Latossolos Húmicos e sua relação com a evolução da paisagem numa área cratônica do sul de Minas Gerais. R. Bras. Ci. Solo, 23:329-341, 1999

SILVA, A.C.; VIDAL-TORRADO, P.; GONZÁLEZ-PEREZ, M.; MARTIN NETO, L. \& VASQUES, F.M. Relações entre matéria orgânica do solo e declividade de vertentes em toposseqüencia de Latossolos do sul de Minas Gerais. R. Bras. Ci. Solo, 31:1059-1068, 2007.

SIMAS, F.N.B.; SCHAEFER, C.E.G.R.; FERNANDES FILHO, E.I.; CHAGAS, A.C. \& BRANDÃO, P.C. Chemistry, mineralogy and micropedology of highland soils on crystalline rocks of Serra da Mantiqueira, southeastern Brazil. Geoderma, 125:187-201, 2005

STEVENSON, F.J. Humus chemistry: Genesis, composition, reactions. 2.ed. New York, J.Wiley and Sons, 1994. 496p.

VELOSO, H.P.; RANGEL FILHO, A.L.R. \& LIMA, J.C.A. Classificação da vegetação brasileira adaptada a um sistema universal. Rio de Janeiro, IBGE, 1991. 124p.

VOLKOFF, B.; CERRI, C.C. \& MELFI, A.J. Húmus e mineralogia dos horizontes superficiais de três solos de campos de altitude dos Estados de Minas Gerais, Paraná e Santa Catarina. R. Bras. Ci. Solo, 8:277-283, 1984.

ZINN, Y.L.; LAL, R.; BIGHAM, J.M. \& RESCK, D.V.S. Edaphic controls on soil organic carbon retention in the Brazilian Cerrado: Soil structure. Soil Sci. Am. J., 71:1215-1224, 2007. 